Portland State University

PDXScholar

$1-1-1983$

\title{
Institutional environments as perceived by the faculty and administrators at six small liberal arts Christian colleges
}

Jeffrey Thomas Fouts

Portland State University

Follow this and additional works at: https://pdxscholar.library.pdx.edu/open_access_etds Let us know how access to this document benefits you.

Recommended Citation

Fouts, Jeffrey Thomas, "Institutional environments as perceived by the faculty and administrators at six small liberal arts Christian colleges" (1983). Dissertations and Theses. Paper 790.

https://doi.org/10.15760/etd.790

This Dissertation is brought to you for free and open access. It has been accepted for inclusion in Dissertations and Theses by an authorized administrator of PDXScholar. Please contact us if we can make this document more accessible: pdxscholar@pdx.edu. 


\title{
INSTITUTIONAL ENVIRONNENTS AS PERCEIVED \\ BY THE FACULTY AND ADMINISTRATORS AT SIX \\ SMALL LIBERAL ARTS CHRISTIAN COLLEGES
}

\section{By}

Jeffrey Thomas Fouts

\author{
A dissertation submitted in partial fulfillment \\ of the requirements for the degree of \\ DOCTOR OF EDUCATION \\ in \\ COMMUNITY COLLEGE EDUCATION
}
Portland State University
University of Oregon
oregon State University
1983


AN ABSTRACT OF THE DISSERTATION OF Jeffrey Fouts for the Doctor of Education in Community College Education presented July 8, 1983

Title: Institutional Environments as perceived by the Faculty and Administrators at Six Small Liberal Arts Christian colleges. APPROVED BY MEMBERS OF THE DISSERTATION COMMITTEE:

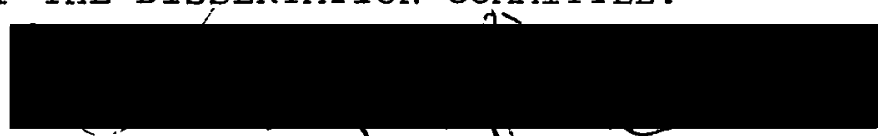

David Willis, Clairperson

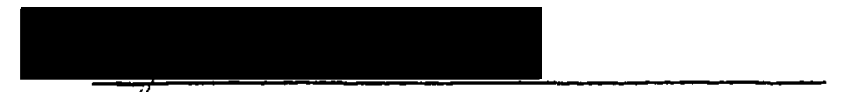
Loyde Hales

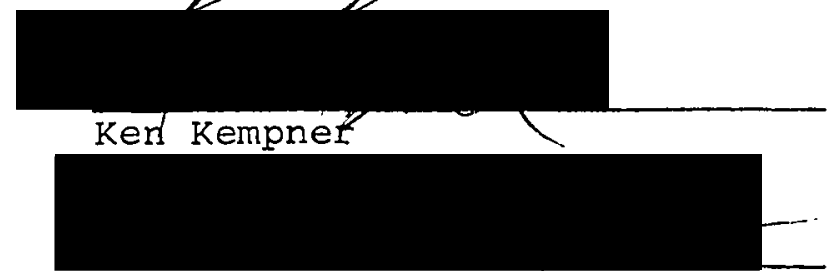

Chadwick Karr

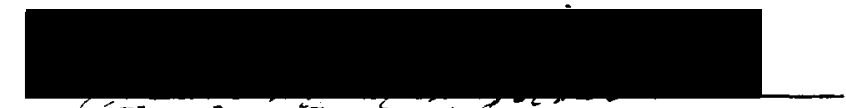

"Charles Carpenter

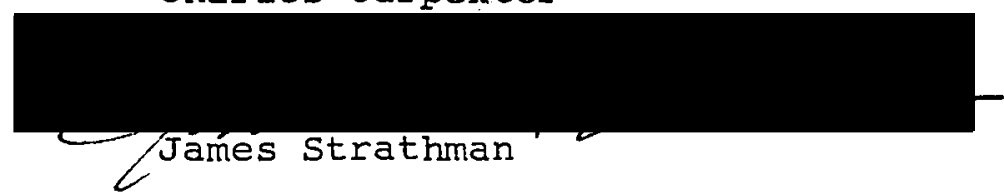

The purpose of this study was to determine if the small liberal arts Christian colleges provide a distinctive environment apart from the traditional classifications 
of colleges and universities. These Christian colleges have been placed in a vulnerable category of colleges for the coming years. It has been suggested that those institutions that most clearly establish their distinctiveness and role in higher education will stand the best chances for survival.

The environments of the six sample colleges were assessed by administering the Institutional Functioning Inventory (IFI) to faculty and administrators. Assessment using the IFI is based on the collective perception technique, and resulted in institutional and total sample mean scores for 11 environmental dimensions.

Statistically significant differences were found among the colleges on eight of the 11 environmental dimensions. However, it was concluded that the colleges constituted a relatively homogeneous group on all dimensions measured except self-Study and Planning.

Total sample means on the 11 scales of the IFI allowed for a generic description of 11 dimensions of the environments at these colleges. They were described as environments low on intellectual-aesthetic extracurriculum activities, human diversity, personal and academic freedom, concern for improving society, and concern for advancing knowledge, while being high on institutional esprit and placing high emphasis on undergraduate teaching and learning. The environments were characterized as having 
moderate amounts of democratic governance, self-study and planning, innovative educational practices, and programs designed to meet the needs of their immediate communities. The sample colleges differed significantly from both the liberal arts colleges and the four-year state colleges on eight of the IFI scales. When compared to the liberal arts colleges, the most notable differences were the considerably lower scores on IntellectualAesthetic Extracurriculum, Freedom, Human Diversity, and Concern for Advancing Knowledge. When compared to the four-year state colleges they were most distinguished by considerably lower scores on Intellectual-Aesthetic Extracurriculum, Freedom, and Human Diversity, and by higher scores on Concern for Undergraduate Learning and Institutional Esprit.

The conclusion of the study is that these colleges do provide a unique college environment. The environments are most distinctive in that they provide few extracurricular activities of an intellectual aesthetic nature, place many restraints on the academic and personal lives of faculty and students, place a low priority on research and scholarship, and are relatively homogeneous in the beliefs and backgrounds of the students and faculty present on campus. It is suggested that additional research focus on other environmental dimensions, student and faculty characteristics, institutional goals, and the value of environments such as these in higher education. 
TO THE OFFICE OF GRADUATE STUDIES AND RESEARCH:

The members of the Committee approve the dissertation of Jeffrey Fouts presented July 8, 1983.

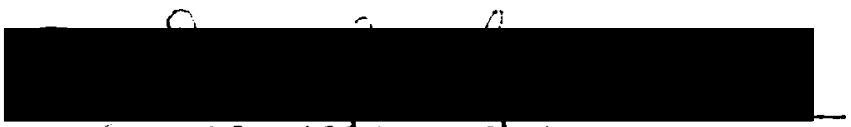

David Willis, Chairperson-PSU

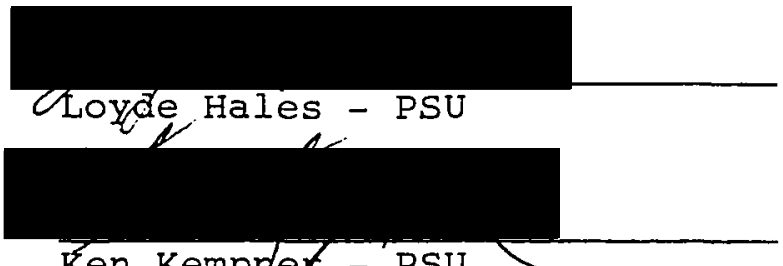

Ken Kempnef - PSU

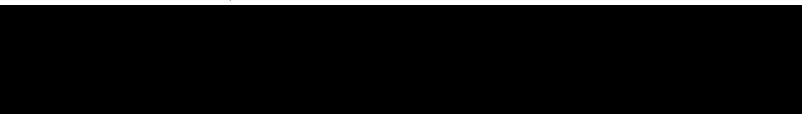

Chadwick Karr - PSU

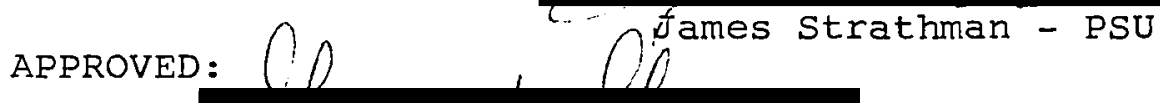

Charles Carpenter - OsU

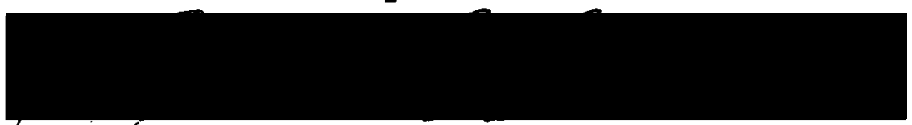

George V. Guy, Tri-University Program Coordinator

(Portland State University)

Max Abbott, Tri-University Program Coordinator

(Uniyersity of Oregom)

Thomas Grigsby, Tri-Univer $/$ ty Program Coordiantor (Oregon State University)

Donald Leu, Dean, School of Education (Portland State University)

Stanley Rauch, Dean of Graduate Studies and Research (Portland State University) 
To Teri, Kara, and Kyle 


\section{ACKNOWLEDGEMENTS}

This research could not have been accomplished without the assistance of numerous individuals. I would like to give special thanks to the six Christian colleges that participated in this study. Their cooperation during some very difficult financial times was an example of the friendliness and caring for which their institutions are known.

The assistance given by my dissertation committee was invaluable. Dr. David Willis' support and Dr. Loyde Hale's research expertise did much to relieve the anxiety and frustration that can often accompany a project such as this. 
TABLE OF CONTENTS

PAGE

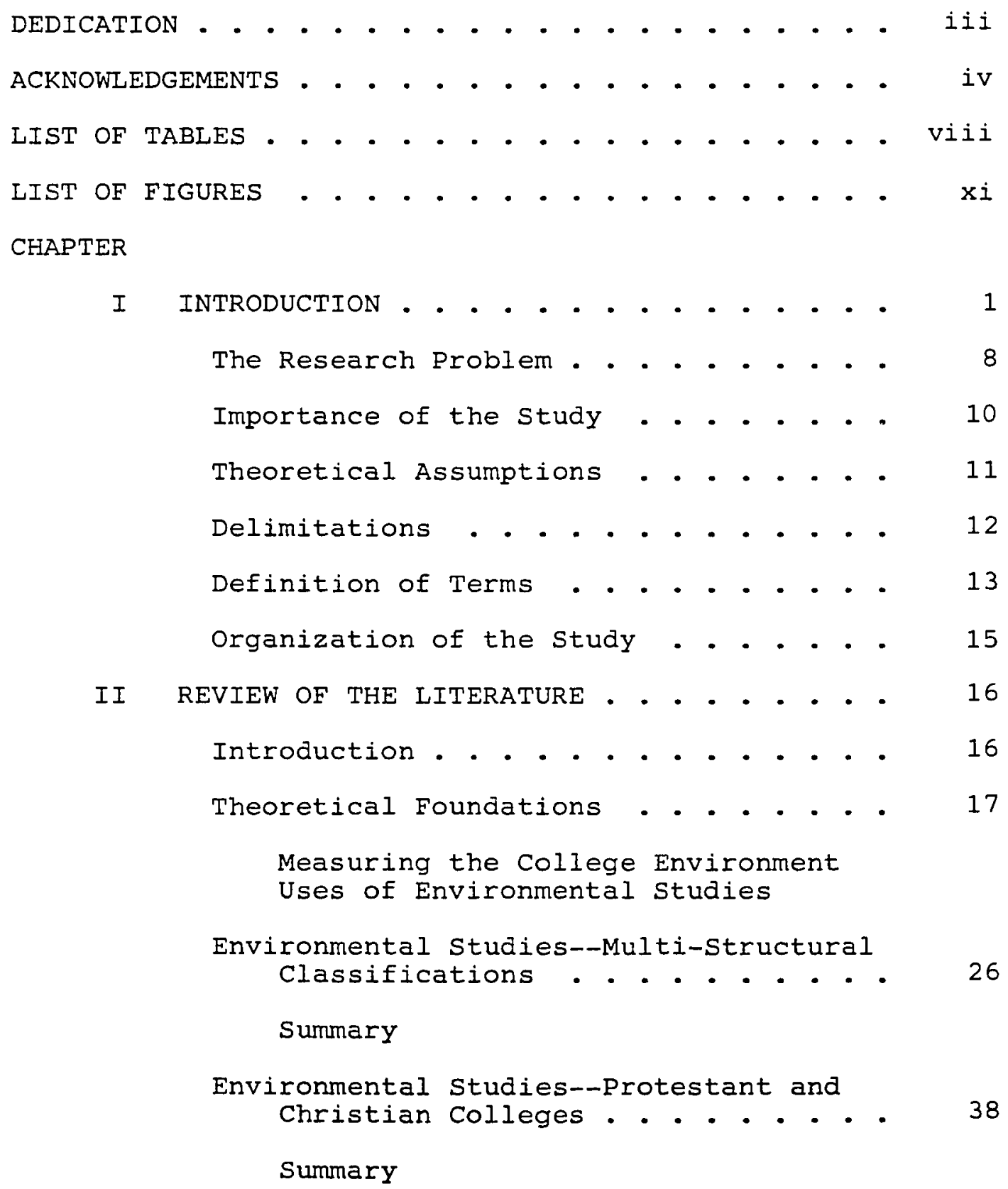


Institutional Functioning Inventory . . 46 Scales and Format Reliability and Validity

Conclusions . . . . . . . . . . 51

III RESEARCH DESIGN AND METHODOLOGY • • • • 53

Sampling Considerations . . . . . 54

Instrumentation . . . . . . . . 55

Data Gathering Procedures . . . . 56

Statistical Design and Hypotheses . . . 57

IV DATA PRESENTATION AND FINDINGS . •. . 61

Analysis by Institution . . . . . . 62

Scale Scores by Institution

Institutional Comparisons

Analysis by Faculty and Administrator

Status . . . . . . . . . . . .

Scale Scores by Faculty and

Adrninistrator Status

Faculty and Administrator Comparisons

Sample Colleges-Normative Data

Comparisons . . . . . . . . 92

Discussion of Findings . . . . . • . 97

Perceptions of the Environments

at Sample Colleges

Environmental Descriptors

Sample Colleges-Normative Data Comparisons

$\mathrm{V}$ CONCLUSIONS AND RECOMMENDATIONS •. . . 105

Summary of the study . . . . . 105

Conclusions . . . . . . . . . 107 
vii

PAGE

Recommendations.......... 110

BIBLIOGRAPHY . . . . . . . . . . . . . . 113 


\section{LIST OF TABLES}

TABLE

PAGE

I Number of Private Colleges with four or

More Years, by Enrollment Size . . . 3

II Coefficient Alpha Reliabilities . . . . 50

III Frequency Distributions by Institution

Intellectual-Aesthetic Extracurriculum • 64

IV Frequency Distributions by Institution

Freedom . . . . . . . . . 65

V Frequency Distributions by Institution

Human Diversity . . . . . . . 66

VI Frequency Distributions by Institution

Concern for the Improvement of Society . 67

VII Frequency Distributions by Institution

Concern for Undergraduate Learning . . 68

VIII Frequency Distributions by Institution

Democratic Governance . . . . . 69

IX Frequency Distributions by Institution

Meeting Local Needs . . . . . . 70

$\mathrm{X}$ Frequency Distributions by Institution

Self-Study and Planning . . . . . 71

XI Frequency Distributions by Institution

Concern for the Advancement of society - 72 
XII Frequency Distributions by Institution

Concern for Innovation . . . . . . 73

XIII Frequency Distributions by Institution

Institutional Esprit . . . . . . . 74

XIV IFI Scale Score Analysis of Variance by

Sample Institution . . . . . . 76

XV Total Sample Frequency Distributions

Intellectual-Aesthetic Extracurriculum • 81

XVI Total Sample Frequency Distributions

Freedom .............. . 82

XVII Tctal Sample Frequency Distributions

Human Diversity . . . . . . . . 83

XVIII Total Sample Frequency Distributions

Concern for the Improvement of society - 84

XIX Total Sample Frequency Distributions

Concern for Undergraduate Learning . . 85

XX Total Sample Frequency Distributions

Democratic Governance . . . . . 86

XXI Total Sample Frequency Distributions

Meeting Local Needs . . . . . . 87

XXII Total Sample Frequency Distributions

Self-Study and Planning . . . . . 88

XXIII Total Sample Frequency Distributions

Concern for the Advancement of Knowledge 89 
XXIV Total Sample Frequency Distributions Concern for Innovation . . . . . . - 90

XXV Total Sample Frequency Distributions Institutional Esprit . . . . . . . 91

XXVI IFI scale Mean Comparisons

Sample Colleges-Iiberal Arts Colleges . 94

XXVII IFI Scale Mean Comparisons

Sample Colleges-Four-Year State Colleges 96 


\section{LIST OF FIGURES}

FIGURE

PAGE

1. Significant Differences Among Colleges

on the IFI . . . . . . . . . . . 77

2. Scale Means for Liberal Arts Colleges and

Sample Colleges . . . . . . . . . . 93

3. Scale Means for Four-Year State Colleges

and Sample Colleges . . . . . . . . . 95 


\section{CHAPTER I}

\section{INTRODUCTION}

"The diversity of American higher education is universally regarded as one of its main sources of strength, reflecting the pluralism in a larger society."

The Carnegie Foundation for the Advancement of teaching - 1975

A major theme that permeates the Carnegie Commission reports $(1970,1971,1972,1973 b)$ of the late 1960's and the 1970's is that the diversity of institutions and programs that make up the American college experience is a positive characteristic and should not only be maintained, but increased. This diverse system was deemed best able to meet the highly distinct needs of a pluralistic society. However, the Commission (Hodgkinson, 1970; Pace, 1974) also found indications that institutions of higher education were growing more alike, thus reducing the diversity. Thus, when formulating its Priorities for Action (1973a, p. 27) the Commission included "the preservation and enhancement of quality and diversity." and recommended that students be allowed to choose among diverse intellectual environments to find one that matches his or her interests and talents (1973b). 
One aspect of the diversity of these American institutions of higher education is that their control is under either public or private agencies. There are some 1500 privately controlled nonprofit two- and four-year schools which enroll approximately 15-20 percent of all college students. These institutions are not a homogeneous group. They provide a rich source of the diversity in educational experience which is available to college students in America.

While the private sector of American higher education declined in percent of total enrollment during the 1970's, it experienced a modest 16 percent increase in enrollment over that decade. In the fall of 1979 the private sector of higher education enrolled 2.5 million students compared to 9 million in the public sector. Of this 2.5 million students, 1.6 million were enrolled in private four-year colleges, an increase from the $1.4 \mathrm{million}$ of five years earlier (National Center for Educational Statistics, 1981, pp. 84, 89). Not only did the overall enrollment increase in the private sector, but the number of four-year private institutions eligible for listing by the National Center for Educational statistics (NCES) increased over this decade. In 1969 there were 1,148 private four-year colleges; in 1974 there were 1,232; and in $1979,1,343$ (NCES, 1970, p. 85; 1975, p. 98; 1981, p. 110). This 
increase was achieved in spite of the closing of over 60 private four-year colleges during this time period (NCES, 1981, p. 116). These closures were partially offset by the opening of new colleges, but primarily by private institutions that had been in existence for some time acquiring eligibility for listing by the NCES (Carnegie Council, 1980, p. 104 ).

TABLE I

NUMBER OF PRIVATE COLLEGES

WITH FOUR OR MORE YEARS, BY ENROLLMENT SIZE

\begin{tabular}{lccc}
\hline Enrollment Size & \multicolumn{3}{c}{ Year } \\
\cline { 2 - 4 } & 1969 & 1974 & 1979 \\
Under 200 & 180 & 213 & 214 \\
$200-499$ & 198 & 213 & 231 \\
$500-999$ & 355 & 341 & 318 \\
$1000-2499$ & 316 & 347 & 402 \\
Over 2500 & 99 & 118 & 151 \\
\hline Total & 1148 & 1232 & 1316 \\
\hline
\end{tabular}

Note. From NCES, 1970, p. $85 ; 1975$, p. 98; 1981 , p. 110 . 
The 1970's saw an increase in the number of small private colleges with four or more years, but a slight decline in the percentage of small colleges with enrollments of less than 2,500. By 1979 these smaller colleges accounted for about 89 percent of the total number of private colleges with four or more years (see Table I).

A large portion of the private sector consists of colleges that are related to or sponsored by a Protestant church. The NCES (1981, p. 111) identified 511 postsecondary institutions that had direct ties to such churches in 1979. The largest group of Protestant colleges is the small, four-year colleges that are found throughout the country. The NCES has identified 280 such colleges; however, Pace (1972) has pointed out that many colleges that are strongly evangelical or fundamentalist are classified by the NCES as independent, not Protestant. He estimated that as of the early $1970^{\prime} \mathrm{s}$, the number of Protestant colleges to be somewhere between 450 and 600 . Included in this number were the colleges of the major Protestant denominations (Lutheran, Baptist, etc.) as listed by the NCES, but also many colleges related to other elements of Protestant Christianity which he termed evangelical or fundamentalist. Since most of these colleges are small, it seems probable that their numbers have increased modestly since Pace's studies, probably 
about the same rate as other colleges of under 2500 in enrollment (see Table I).

The past two decades have seen a decline in the importance of the small Protestant colleges as comprehensive state college and university systems and local community colleges have grown in number and influence. While private colleges have been enrolling an increasingly smaller percentage of all college students, the Protestant colleges have been enrolling an increasingly smaller percentage of all private college enrollment. Between 1965 and 1977 religiously affiliated liberal arts colleges increased their enrollments by only 11 percent, as compared to 55 percent by the non-religious private colleges (Leslie, 1981, p. 43). Although many of these Protestant colleges remain very active and vital, others struggle for existence.

A number of Protestant liberal arts colleges are self-described as "Christian" colleges. These colleges are generally more conservative in nature, and see their purpose as one of developing not only the social, emotional, and academic life of a student, but the spiritual life as well. Their proclaimed purpose is to provide instruction and a living environment that will foster a given faith, while at the same time providing academic training in keeping with that faith. These 
Christian colleges vary in size, but many are very small, underendowed, and extremely dependent on tuition and gifts for survival.

The future of these Christian colleges is uncertain as higher education moves into a long period of potentially declining enrollments. The dominant statistic that has engaged educational planners in recent years is the decline in the number of traditional college-age students, a decline which has already begun and will continue throughout the $1980^{\prime}$ 's and into the 1990's. The declining birth rate which began in the $1960^{\prime}$ 's will cause a 15 percent decrease of traditional college age students between 1980 and 1990 , a loss of some 2.6 million potential students. This liena is expected to continue until 1996, causing a decrease of 24 percent between 1980 and 1995 (NCES, 1982, p. 126). Centra (1980) and others have identified and discussed several other factors that will affect college enrollments in the future. It is apparent that some private colleges face a potentially severe problem in attracting students in sufficient numbers to remain viable.

In addressing this situation the Carnegie Council (1977, p. 17) recognized that it is misleading to overgeneralize about the private sector, for different parts of it behave in quite different ways from others. 
The Council has noted that the academically elite sector has demonstrated comparative stability in recent years, while there have been great differences in the experiences of the less selective liberal arts colleges. Some have increased their enrollments and financial positions dramatically, while other colleges have drastically declined. The Carnegie Foundation (1975), Brooks (1980), and others have maintained that the colleges in the most vulnerable category in the coming decade will be the less selective liberal arts colleges with small endowments. These colleges are usually gift-dependent, and particularly vulnerable if they are small in size with high fixed overhead costs, and thereby less able to absorb a drop in enrollment and remain solvent. A large number of small Christian colleges fall in this category.

The Protestant college has been duly recognized for its distinctive nature and role in higher education (Pace, 1972), but it is also known that there is considerable diversity within this group of colleges. The potential closure of many of the small Christian colleges represents a real threat to this diversity. A common theme in the current literature is that those institutions with the clearest statement of mission and identity, and with a constituency that believes in that mission will be in the strongest position to survive. 


\begin{abstract}
Comparisons and descriptions of educational institutions have generally relied on data about enrollments, costs, course offerings, size of the library, percentage of the faculty with doctorates, and the like. However, the college experience is more than books and courses. It is an entire system of policies, activities, and pressures that influence and change students during the college years. These environmental characteristics which differ from institution to institution are a major source of diversity in higher education. Various research studies have shown that these various environments affect student attitudes, activities, and development. A number of studies have shown that environmental characteristics of college campuses differ, depending on type of governance, size, location, religious affiliation, institutional purpose, etc. Consequently, it is believed that each type of college offers a unique educational experience.
\end{abstract}

\title{
The Research Problem
}

It is known that small liberal arts Christian colleges differ from most other colleges in the size of the library, percentage of faculty with doctorates, and similar measures. But these colleges have maintained that they do, indeed, provide a unique learning environment in other 
ways. Taxonomies of colleges and universities usually classify the small, liberal arts, Christian colleges under the headings of "liberal arts colleges," or "Protestant colleges." However, research on the environments of liberal arts, Protestant, and Christian colleges shows that the range of environmental characteristics is great among these groups, and that size and religious affiliation may affect the environment.

The purpose of this study was to determine if the small liberal arts Christian college provides a distinctive college environment, apart from the traditional classifications of colleges and universities, and thereby fulfill a distinctive role and function as an educational institution. The following research questions were addressed :

1. What type of institutional environments are perceived to exist by faculty and administrators at small liberal arts Christian colleges?

A. What are the common perceptions of the environment among these colleges?

B. Do the perceptions of the environment differ significantly among these colleges?

C. Are there significant differences between the faculty's perceptions of the environment and the administrations's perception of the environment? 
2. How do the faculty's and administration's perception of the environment at these colleges, as a group, compare to the faculty's and administration's perceptions of the environments at colleges in traditional classfications of higher education?

A. Private liberal arts colleges. B. Four-year state colleges.

\section{Importance of The Study}

Research on such schools is lacking and was needed for the following reasons:

1. The environmental diversity offered by the numerous types of institutions is threatened by the forecasts of closure of many small liberal arts Christian colleges. It is maintained that many of these colleges are headed for extinction unless thay can clearly establish their distinctiveness and role in the higher education scene and communicate that distinctiveness to a select constituency. This study provides preliminary normative data that will aid in the identification of that distinctiveness. If the nature of the environments of various types of colleges is understood, then informed decision-making on the part of parents, students, counselors, and recruiters may 
take place.

2. Such data can be of significant use by administrators in institutional evaluation, planning, and self-study. For example, an institutional goal to develop student awareness of political and social trends and events may be evaluated in light of data on environmental characteristics in that area. Decisions may then be made to enhance those elements of the environment, or may result in goal clarification.

3. These data provide the basis for administrators, educational planners, and others interested in the survival of these types of colleges to do further research on student characteristics, institutional goal-environment congruence, and the effects of the college experience on the students -- all important elements in determining the colleges' role and distinctiveness.

\section{Theoretical Assumptions}

The fact that college campuses differ in the type of environment they provide to students is widely accepted. Attempts at measuring these differences have centered around three techniques: (1) assessing the personal characteristics of individual within the environment, (2) 
assessing how people behave in the environment, and (3) assessing people's perception of the environment. Each method has provided different scales representing different dimensions within the environment, but there is some commonality. Measurements using these techniques have continually resulted in differing scores among similar and different types of institutions. The theoretical assumption central to this study is that the collective perception technique is a valid method for assessing specific dimensions of a college environment.

\section{Delimitations}

There are numerous descriptors that might be employed to classify colleges. This study was limited to the classifications of colleges that are small in size, liberal-arts oriented, and self-proclaimed "Christian" in emphasis.

Likewise, the concept "environment" has many dimensions and has been assessed in various ways. The dimensions to be assessed and compared in these six colleges were limited to the 11 scales of the Institutional Functioning Inventory (Peterson, Centra, Hartnett, \& Iinn, 1970), based on the collective perceptions of faculty and administrators. 
The student body of an institution of higher education is an integral part of the college environment. Their perceptions of the environment may differ significantly from that of the faculty and administrations. However, this study was limited to the collective perceptions of the faculty and administrators for the following reasons:

1. The nature of the IFI is such that it is recommended by the authors (Peterson, et al., p. 10) for use primarily with faculty and administrators.

2. Hartnett and Centra (1974) have demonstrated that with the IFI a very high correlation exists between student responses and the responses of faculty and adm inistrators.

3. For practical considerations, the number of students needed for a satisfactory sample at each college would have created a total sample response prohibitive in size.

\section{Definition of Terms}

Small, when referring to college size, shall mean those colleges that have an enrollment of under 500 students, full-time equivalent. 
Liberal arts colleges shall mean those colleges: (1) whose catalogs identify themselves as a liberal arts college or emphasize the importance of liberal arts education; (2) whose catalogs reflect course offerings in the arts, sciences, and humanities; and (3) that are accredited by a regional accrediting agency

Christian colleges shall mean those colleges that have catalog statements to the effect that a Christian environment or Christian education is of major importance or a major purpose of the college.

Faculty shall mean those college personnel engaged in teaching college credit cources. This term includes: (1) all full-time teaching faculty; (2) adjunct teaching faculty that teach one or more courses per quarter/semester; and (3) those who have both teaching and administrative assignments, if the administrative responsibility is less than 50 percent of the total assignment.

Administrators shall mean those persons whose assignment is 50 percent or more in administrative responsibilities.

Environment shall mean the multi-dimensional network of personal and social forces, and conditions that affect the lives of students and their development. 
Organization of the study

Chapter II contains a review of the literature on classifications of institutions of higher education and the research that has been done on college environments, particularly small colleges and Protestant Colleges.

Chapter III presents a description of the research design and methodology including design of the investigation, college selection, instrumentation, data gathering procedure, hypotheses, and statistical design. Chapter IV is a presentation of the data on the colleges studied and their responses to the 11 scales of the IFI.

Chapter $V$ is a summary of the findings, conclusions, and recommendations for further research. 
CHAPTER II

REVIEW OF THE LITERATURE

\section{Introduction}

A common approach to the classification of institutions of higher education was demonstrated by the Carnegie Council (1976). Their intent was to group colleges homogeneously based on the functions of the institutions and the characteristics of the students and faculty members. Their classifications fell into five main categories.

1. Doctoral-Granting Institutions

2. Comprehensive Universities and Colleges

3. Liberal Arts Colleges

4. Two-year Colleges and Institutes

5. Professional Schools and Other Specialized Institutions The classification of Liberal Arts Colleges was further broken down into Liberal Arts Colleges I and II with the selectivity in admissions and achievement of the college graduates as criteria for these subcategories. 
While several studies (Feldman and Newcomb, 1969; Rick and Jolicoeur, 1979) have shown that these "structural" classifications may be of value for generalizing about the impacts of college on student development, the adequacy of such classifications has been questioned. Jonsen (1978, p. 10) maintained that because the categories were defined using size, selectivity, complexity, and function as qualifiers, "the extent to which they distinguish among institutions in terms of purpose and outcomes is somewhat limited." Similarly, there is considerable research to show that colleges within these structural categories differ significantly on numerous environmental dimensions which are thought to affect student development.

The review of the literature focuses on the theoretical foundations of environmental research, environmental studies of multistructural classifications, environmental studies of Protestant and Christian colleges, and a review of the Institutional Functioning Inventory, the instrument used in this study.

Theoretical Foundations

Stern (1970) is representative of the theoretical framework for discussions and research into the college 
environment. The contention of researchers interested in the college environment is that the traditional criteria for evaluating colleges and universities emphasize the easily quantifiable characteristics of these organizations, such as number of students, number of faculty, number of books in the library, teaching load, buildings and grounds, endowment assets, curricula offerings, etc. Regional accrediting agencies and national associations have relied heavily on these statistical appraisals for classification and comparison of institutions. While in some ways appropriate, these are limiting characteristics and do not describe thoroughly the unique natures of the various types of institutions.

Stern (1970) pointed out that traditional quantifiable standards applicable to one type of college are not necessarily appropriate for other types of colleges. For example, the standards appropriate to a medical school are not relevant to a seminary. Once this is accepted, a separate basis for evaluation can be developed: "The common questions, appropriate to any educational institution, are not 'What are its physical assets?' but 'What is it trying to accomplish?' and not 'How much has it got?' but 'How well does it achieve it objectives?' (p. 3)." Stern noted that objectives in higher education generally stress knowledge and intellectual 
skills, and rightly so. However, in adddition, numerous other goals are sometimes expressed for growth or change in attitude and values, personal and social development, citizenship, civic responsibility, aesthetic appreciations, and similar affective attributes.

In relation to such complex objectives, a college community must be viewed as more than classrooms, professors, libraries, and laboratories. It is also a network of interpersonal relationships, of social and public events, of student government and publications, of religious activities, of housing and eating, of counseling, and of curricular choices. . . The college community may be regarded as a system of pressures, practices, and policies intended to influence the development of students toward the attainment of institutional objectives. The distinctive atmosphere of a college, and the differences between colleges, may be attributable in part to the different ways in which systems can be organized, to subtle differences in rules and regulations, rewards and restrictions, classroom climate, patterns of personal and social activity, and other media through which the behavior of the individual student is shaped (p. 4).

From this perspective, stern was interested in finding better ways of characterizing the differences that existed among colleges, particularly as they might affect student development.

Measuring The College Environments

The fact that college environments differ from one another in many ways is generally accepted. Measuring these differences within which learning, growth, and 
development take place has been attempted a number of ways. The assessment tools that have been devised generally employ one of three techniques: (1) assessing the personal characteristics of individuals within the environment, (2) assessing how people behave in the environment, and (3) assessing people's perception of the environment. The first two techniques are considered more objective measures, in that they allow the enumeration of specific characteristics or specific behaviors, while the perception approach is much more subjective in nature on the part of the person reporting. Chickering (1972) has recognized that, while there is some commonality between the subjective and objective measures, an understanding of both is important for planning and evaluation. Each tool that has been designed has its own scales or dimensions of the environment it purports to measure. Consequently, the assessment of the environment may vary greatli, depending on how and what tool is used to assess the environment (p. 141).

The approach for assessing the personal characteristics of individuals within the environment is demonstrated by the Environmental Assessment Technique (EAT). Developed by Astin and Holland (1961), it assumes that the environment is a product of the quantifiable personal characteristics of the students of the college. 
The EAT analyzes the environment in terms of eight characteristics possessed by the student body: average intelligence, size, and six personal orientations, including realistic, scientific, social, conventional, enterprising, and artistic. The Inventory of College Activities (ICA) developed by Astin (1968) is an example of an assessment tool that attempts to measure the environment through the behavior of the people involved. The ICA asks for a reporting of behaviors in the peer, classroom, administrative, and physical environments. However, the most common method for assessing the environment is the assessment of people's perceptions and image.

Measurements of the college environment that rely on the image or perception of the environment can be traced back to Henry A. Murray's (1938) psychological needs-environmental press theory of behavior. Stern (1970) discussed the problem of the potential disparity between the perceived environment and the actual one. Yet, it is believed that each person reacts to his or her own perceptions of a situation, and for that person, the perception is reality. These perceptions, in theory, are said to be both personal and consensual, since the environment consists of others confronting the same circumstances. The estimates of the environmental forces by most people, are thought to be working on others, as 
well as oneself. Therefore, "the collectively perceived significates of various press are an entirely adequate source from which to infer the environmental situation to which individuals are responding (Stern, p. 12)." The College Characteristics Index(CCI) of Pace and Stern (1958) was the first assessment tool based on perceptions and which provided institutional scores on factors such as group life, social form, student dignity, self-expression, aspiration level, vocational climate and intellectual climate. Pace $(1963,1969)$ modified the CCI to form the College and University Environment Scales (CUES). Widely used during the 1960's and $1970^{\prime} \mathrm{s}$, CUES provided perception scales identified as practically, community, awareness, propriety, and scholarship. The scoring of this tool emphasized the collective perceptions of the people assessed. If the students agreed by a two-to-one margin or greater that a statement was true about that college, it was counted as a college characteristic. An institutional score is derived for each of the scales based on this technique.

The most recent environmental assessment tool to employ the collective perception theory is the Institutional Functioning Inventory (IFI) developed by Peterson, Centra, Hartnett, and Linn (1970). One significant difference between the IFI and its predecessors 
is that it was designed to be used primarily with faculty and administrators, and not with students. Harnett and Centra (1974) have shown that with using the IFI, faculty perceptions of the academic environment are remarkably similar to the perceptions of students and administrators, suggesting a common perception of the environment, rather than differing environmental perceptions for each group. Pace (1969b) maintained that regardless of the approach used, there appeared to be some common dimensions of the environment that emerged. All of the studies found some type of intellectual or scholarly dimension, a social awareness dimension, a vocational or pragmatic dimension, a friendiness or community dimension, and a social conformity dimension. Similar findings were reported by Wright (1973). Considering these dimensions Pace (1969b) concluded :

What has been demonstrated is that colleges differ greatly from one another in many measurable characteristics. . . Moreover, the accumulated results indicate clearly that the common classifications of institutions mask a great deal of diveristy. For example, liberal arts colleges, as a class, run the gamut from top to bottom scores on all five of the dimensions measured by CUES (p. 172$)$.

In summary, it is recognized that colleges differ from one another in various intangible ways. While the traditional structural classifications provide some insight into the differences, they provide an incomplete picture of 
the individual nature and environment of each college. Various indirect measures have been developed to assess these environmental characteristics, using both objective and subjective techniques. As research instruments, they have demonstrated the existence of numerous environmental dimensions not discernable within the structural taxonomy system.

\section{Uses of Environmental Studies}

The environmental assessment techniques described have been used by various institutions and researchers for a number of purposes. One common use is for institutional self-study, evaluation, and planning. Research for this purpose may be general in nature (Grant, 1975), may focus on institutional goals-environmental congruence (Nell, 1973; Kroeker, 1973), or to compare the real and ideal environments of the institutions (Spangler, 1972; Benn, 1975). The ultimate purpose of such studies is to alter or improve the institutional environment, and Menne (1967) has designed a paradigm for such environmental manipulation. The need and value for such environmental changes for affecting student develoment has been demonstrated by Chickering (1972).

Institutional self-studies employing environmental assessments have also focused on the perceptions of various 
subgroups within the environments. Nelson (1972), Lawson (1974), deArmas and McDavis (1981), Roussell (1974), Windham (1973), Goodwin (1980), and Kuh and Sturgis (1980) have shown that student perceptions of the environment are subject to change and depend on numerous factors, such as sex, age, year in school, and residential status. Similar studies by Hamilton (1979), McDonald (1972), Murray (1972) and Madrazo-Peterson and Rodriquez (1978) have demonstrated that ethnic differences play a large factor in the perceptions of the environments. These perceptions may play a significant role in student attrition and transfer (Anstett, 1973; Guth, 1974; Wildman, 1972). It is known that college students change during the college years. However, using environmental studies to assess the impacts of those environments on student development is complex and has yielded unclear results. Chickering, McDowell, and Campagna (1969) have articulated those problems, while Stern (1970) has shown considerable evidence that the college environments are as much determined by the nature and development of the students when they enter as anything else. Certain types of colleges have been shown to attract certain types of students headed in a certain developmental direction already. Attributing continued development to the environment is problematic. It may not be valid to assume that certain environmental characteristics foster 
development in certain academic, personal, social, and spiritual areas. The students may have already been programmed for that development before they entered the college.

Several larger research projects have used envirommental studies in an effort to identify the commonalities and dissimilarities among various structural classifications of institutions. Those findings have demonstrated the inadequacy of such labels and the need for further research, understanding, and refinement.

\section{Environmental Studies -- Multi-structual Classifications}

Research on the environments of colleges and universities drawn from the major traditional structural classifications does show that some generalizations about the environments are possible. Yet, it aiso shows chat those generalizations are very broad, and therefore unsatisfactory, with further refinement needed.

Astin (1965) was primarily concerned with what type of student attended what type of college. If the theoretical assumption that the characteristics of the college environment are largely dependent on the characteristics of the student body (Astin and Holland, 1961 ) is accepted, then this research provides some insight 
into the differing natures of various types of colleges. Astin looked primarily at "freshman input factors"; that is, the personal characteristics of entering freshmen at different types of colleges. Through statistical procedures 52 measures were reduced to the six student characteristics of Intellectualism, Estheticism, Status, Leadership, Pragmatism, and Masculinity.

The most outstanding results showed that on the Intellectualism scores the technological institutions were very far above all other classifications, while the Protestant liberal arts colleges, teachers colleges, and public liberal arts colleges scored very low. Likewise, on Pragmatism the technological institutions were over two standard deviations above the rest of the colleges. The Catholic and the private nonsectarian liberal arts colleges scored highest on Estheticism and the Catholic universities lowest, while scoring highest on Masculinity. of particular interest to this study, the Protestant liberal arts colleges scored at the mean on Leadership and below the mean on all five other characteristics, particularly Intellectualism. The four categories of liberal arts colleges exhibited considerable diversity on all characteristics except masculinity.

Astin (1968) conducted a major research project during the early 1960 's, involving over 30,000 students and 
representing over 200 institutions. His approach for asessing the college environments employed the Inventory of College Activities (ICA) that focused primarily on student behaviors (e.g., amount of time spent studying, frequency of intellectual arguments) and delineated four broad categories: (1) the peer environment, (2) the classroam environment, (3) the administrative environment, and (4) the physical environment. Also included in the ICA was an assessment of the college image (e.g., this is a highly competitive environment) and student personal characteristics (e.g., academic ability, need achievement). Among Astin's classifications for analysis and environmental descriptions were type of curriculum (university, liberal arts college, teacher college, and technological institution) and type of control (public, private non-sectarian, Roman Catholic, or Protestant). Among his findings the typical university differed in several ways from other categories of institutions. He found that the peer environment was characterized by high competitiveness, high frequency of formal dating, large amounts of drinking, limited participation in musical and artistic activities, and low cohesiveness. Surprisingly, even though with larger and better library facilities, Iibrary use was infrequent. The common assumption that larger universities tend to be impersonal was supported by 
the research. Unfamiliarity between the students and faculty, noninvolvement in class activities, and severe grading practices were common characteristics that supported this generalization. All 16 of the lowest scoring institutions on the factor reflecting concern for the individual were universities. Institutional policies against cheating and aggression were about average with other types of institutions, while policies on drinking and heterosexual activites were quite lenient.

The teachers' colleges and the technological institutions had distinguishing characteristics. The teachers' colleges were described, among other things, as having environments high on femininity, large amounts of leisure time, low personal interactions with class instructors, little concern for the individual, and low school spirit. Technological institutions formed the most distinctive and homogeneous classfication with high manifestation of competitiveness, independence, and verbal aggressiveness; and with low emphasis on social and traditional college life.

In contrast, only a relative few generalizations were possible about the liberal arts colleges because of the diversity exhibited. The few common characteristics reversed the tendencies of the universities, in that the liberal arts colleges demonstrated a cohesive and 
cooperative peer environment, familiarity with the instructor, and a high degree of concern for the individual. Significant is the fact that Astin (1968) concluded that because of the wide range of scores on the ICA and the environmental diversity, "the liberal arts college has limited functional significance as a category of institutions (p. 122)." When examining the colleges by type of control, Astin found that thepublic institutions tended to exhibit peer environments that were competitive, and with little cohesiveness, independence, and musical and artistic activity. There was little familiarity with the instructor and severe grading practices. Nine-tenths of the public institutions were characterized by low concern for the individual. In short, much like the classification "university."

Because previous research (Astin, 1965) had shown that the designation "private" control was inadequate due to the great variations within the private sector, in this study Astin (1968) further divided the category to include non-sectarian, Catholic, and Protestant. The private, nonsectarian institutions were found to enroll students that were independent and participated in few religious activities. They engaged in large amounts of drinking and showed a tendency toward verbal aggressiveness. The environments were "snobish" with permissive attitudes and 
lenient disciplinary procedures concerning aggression, drinking, and heterosexual activity. From the research emerged two distinct subgroups: (I) the prestigious, selective colleges that had not had religious ties for many years, and (2) those institutions who had recently severed ties with a religious group.

The Catholic institutions were distinguished by environments that provided little leisure time, frequent use of the library, frequent conflict with regulations, little familiarity between students and faculty, high academic competitiveness, high school spirit, and severe discipline policies in all areas. The classification "Protestant" included those colleges that were affiliated with some Christian denomination apart form the Roman Catholic or Orthodox Churches, thus including a wide range of colleges. Their enviromments differed from other colleges in that they were highly cohesive, with much student-instructor familiarity, a characteristic Astin maintained was due in part to the small size of the Protestant colleges. The environment was viewed by the students as somewhat restrictive, with many religious activities and little drinking.

One of the more interesting findings of Astin (1968, p. 131), but not surprising, was the influence of the size of the student body on various environmental 
characteristics. Specific findings showed that size of the student body was strongly related to the following dimensions: Concern for the Individual Student $(r=-.72)$; Spread of the Campus $(r=.67)$; Involvement in the Class $(r$ $=-.58)$; Familiarity with the Instructor $(r=-.52)$; Competitiveness (vs. cooperativeness) $(r=.45)$; and Cohesiveness $(r=-.42)$. These findings support the general notion that large institutions are depersonalized and smaller ones more concerned with the individual.

Astin (1968) concluded:

it is now clear that colleges do not differ along just one or even a few measurable dimensions. Thus, any attempt to describe colleges in terms of only one or two factors, such as size or prestige, represents a drastic and perhaps destructive oversimplication. Purthermore, the absolute difference among institutions in the frequency with which the stimuli that make up each environmental dimension occur are considerable. Many stimuli are reported by virtually none of the students at others. In short, this study demonstrates that institutional environments in American higher education are extraordinarily diverse, both quantitatively and qualitatively (p. 139 ).

A third major research project was conducted by Stern (1970) in developing the College Characteristic Index (CCI) during the early 1960's. Intellectual climate was determined by the covariance of eight of the 11 CCI factors, while the same method assessed the nonintellectual climate made up of five factors. 
Among Stern's six classifications of colleges were independent liberal arts, denominational liberal arts, university-affiliated liberal arts, business administration, engineering, and teacher training. When comparing the denominational, university affiliated, and independent liberal arts colleges, the latter were characterized by noticeably higher scores on all eight factors of the intellectual climate, and lower scores on all the non-intellectual climate factors except selfexpression. The two other types of liberal arts colleges were below average in intellectual climate, with the denominational colleges particularly low on pressure for academic achievement. Conversely, they tended to be above average on non-intellectual climate, stressing group life, vocationalism, and social conformity. Engineering schools were most distinguished by their high scores on the factors of aspiration level and academic achievement. Teacher training colleges and business administration colleges were characterized by below average scores on all eight factors of intellectual climate.

Religious affiliation of the college was also used by Stern to analyze the data. Catholic, major Protestant (Baptist, Episcopalian, etc.) and other Protestant sects (Mennonite, Quaker, etc.) provided the basis for grouping and comparisons. The differences were significant for all 
factors among these three classifications. The two groups of Protestant colleges differed on intellectual climate, with the other Protestant sects scoring significantly higher in this area. These colleges also scored significantly higher on the factors of student dignity, self-expression, and group life. Notable were the low scores on the intellectual climate factors for the Catholic colleges.

An important element in determining institutional environments emerged when stern compared these religiouslyaffiliated colleges by size. The Catholic colleges had considerably larger enrollments than the Prostestant colleges, and scored significantly lower on intellectual climate. The study demonstrated an inverse relationship between size and intellectual climate, which reduced the disparity between the Catholic and Protestant colleges. Stern concluded: "it would appear that the distinctive qualities of church-controlled schools tend to be a function of their common administrative limitations rather than the specific religious ethos per se (p. 111)." This was supported by additional data from the study (p. 146) that showed that low scoring institutions on intellectual climate had enrollments, on the average, of nine times greater than high intellectual climate institutions. 
The College and University Environment Scales (CUES) was used by Pace (1972) to assess the environments of 160 colleges between 1966 and 1970. CUES provided scores on five scales: (1) practicality (enterprise, organization, social activities, etc.); (2) community (friendly, cohesive); (3) awareness (social, personal); (4) propriety (concern for rules, politeness); and (5) scholarship (academic competitiveness, scholastic interest). Pace used three main classfications of colleges; universities, liberal arts colleges, and Protestant colleges, with the latter divided into two subgroups, mainline denominational and evangelical-fundamentalist. These two subgroups were comparable to Stern's designations for Protestant colleges. Pace's findings showed a wide range of scores for all classifications of colleges on the scholarship scale. The Protestant colleges differed among themselves as much as did the universities and liberal arts colleges, permitting only weak generalizations. However, the tendency was for the Protestant colleges to score lower overall on this scale, with 66 percent of the mainline denominational colleges and 67 percent of the evangelical-fundamentalist colleges scoring at or below the national median, compared to 50 percent for the universities and 40 percent for the liberal arts colleges ( $p .24)$. 
The same range of diversity was exhibited on the awareness scale by the universities and liberal arts colleges, while the protestant colleges were more homogeneous and scored considerably lower on the scale overall. Homogeneity was demonstrated by all three classifications of colleges on the community scale, with the universities considerably below both the liberal arts colleges and the Protestant colleges on this environmental dimension. Likewise, the highest scores on the propriety scale were obtained by the liberal arts and Protestant colleges.

In general then, the universities were characterized by high scores on awareness and practicality, average scores (but with a wide range) on scholarship, and low scores on community and propriety. The liberal arts colleges were high on scholarship (but again with a wide range), awareness, community, and propriety, and somewhat below average on practicality. The Protestant colleges, as a whole, exhibited environments high on practicality, propriety, and community, while being somewhat below average on awareness and scholarship. The distinctions between mainline denomination and the evangelicalfundamentalist colleges will be discussed in the next section. 
Summary

Generalizing from the research of Astin (1965, 1968), Stern (1970), and Pace (1972) must be done with caution, considering that in some cases the data are 20 years old. In addition, the researchers used different assessment tools, thus measuring different dimensions of the college environments, and although similar, their classification systems for the colleges varied. Nonetheless, within these limitations important conclusions are possible. First, they have demonstrated that, for many dimensions of the environment, the wide range of scores within a single structural classification allowed for only the broadest of generalizations, with the recognition that there were a number of exceptions.

Second, they have also demonstrated that despite the diversity within any structural classification, certain tendencies did emerge concerning various environmental dimensions. For example, the larger universities were generally characterized by an impersonal nature, low concern for the individual, limited contact between faculty and students, high academic competitiveness, and high social political awareness--not a great deal unlike the typical stereotype of a large university. In comparison, the liberal arts colleges, on the whole, demonstrated a cohesive student body, high concern for the individual, and high familiarity between the 
students and faculty--in short, a more friendly congenial environment. Yet all three researchers recognized, and were supported by the data, that this category contained many distinct subgroups worthy of independent research. These subgroups appeared to be a function of degree and type of religious affiliation and size of the student body. So unlike were many of these colleges, Astin (1968) went so far as to question the validity of the category "Iiberal arts colleges."

Environmental studies--Protestant and Christian Colleges

The vast majority of liberal arts colleges trace their origins to a particular religious group or movement. Today, the extent to which those religious ties play a role in directing the affairs of the college varies from only a historicul connection to complete control of the curriculum, administration, and student recruitment and life. Keeton (1971) and Pace (1972) have ably defended this state of affairs. They believe the philosophical and educational diversity found among liberal arts colleges to be a definite strength and resource in American higher education. Researchers studying the environments of liberal arts colleges have attempted to include this religious connection in their analysis, resulting in 
various taxonomies under the broad heading "liberal arts." Consequently, the overlapping of classifications is great. The research has focused on (1) liberal arts colleges with various Protestant and Christian college subcategories; or on (2) Protestant and Christian colleges, many of which are liberal arts colleges.

Astin and Lee's (1972) research focused on the small, private colleges with limited resources. Labeled the "Invisible Colleges" based on the small size and low selectivity in admissions, their study included a number of small, liberal arts colleges with religious ties. In fact, one of the major distinguishing characteristics of the invisible college classification was religious affiliation. The Inventory of College Activities(ICA) was used to assess the environments of these invisible colleges using three categories: private nonsectarian, Protestant, and Roman Catholic.

Differences in the peer environment on the ICA emerged among these three categories. Roman Catholic colleges scored more than two standard deviations above the nonsectarian colleges on the conflict with regulations factor. Both the nonsectarian and Protestant students manifest more independence than students from the Roman Catholic colleges. Protestant college students engage in less leisure activities, less drinking, and fewer informal 
dates, while participating in more religious activities. As expected, the classroom environment of the Protestant colleges is distinguished by friendiness between the instructor and student, while the setting is most formal in the Catholic colleges.

Astin and Lee (1972) concluded that the invisible colleges were not homogeneous, but differed on several environmental dimensions. One limitation of the study is that they did not consider the interaction of size of enrollment with the levels (categories) of small colleges: nonsectarian, Protestant, and Roman Catholic. Of important note is the fact that they found the private invisible college environments to be more similar to public colleges than to elite private colleges. This was emphasized in their statement that

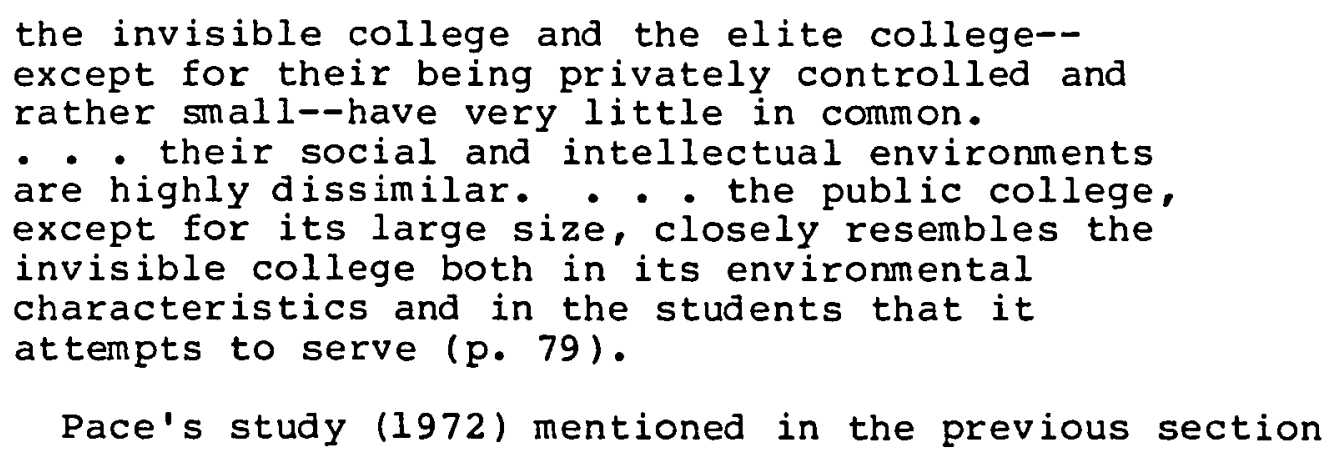

Pace's study (1972) mentioned in the previous section not only compared protestant colleges to universities and independent liberal arts colleges, but also compared two types of Protestant colleges (mainline denominational and evangelical-fundamentalist) and the differences of the 
environments with the factor of strength of church connections. Mainline denominations included the colleges of the Presbyterians, Episcopalians, Disciples, Congregationalists, Baptists, Methodists, and Lutherans, while the evangelical-fundamentalist category contained the colleges of most other Protestant religious groups.

On the CuEs scholarship scale, both categories of Protestant colleges exhibited a wide range of scores, with similar distributions and means. The awareness scale produced comparable results. Both mainline denominational and evangelical-fundamentalist colleges scored very high on community, with the latter scoring slightly higher. However, significant differences emerged on the propriety and practicality scale, with the evangelical-fundamentalist colleges scoring noticeably higher on both. On the propriety scale 93 percent of the evangelicalfundamentalist colleges scored at or above the national median, compared to 76 percent for the mainline denominational colleges, and 100 percent to 52 percent on the practicality scale (pp. 29-30).

The six types of denominational connections identified by Patillo and Mackenzie (1966) were used by Pace (1972) to examine the effect of the strength of church connections on the college environment. The six relationships identified included: (1) board of control 
includes one or more members of church and/or members nominated or elected by the church body; (2) ownership of the institution by the religious body; (3) financial support by the religious body: (4) acceptance by the institution of denominational standards or use of the denomination name; (5) institutional statement of purpose linked to a particular denomination or reflecting religious orientation; and (6) church membership a factor in selection of faculty and administrative personnel.

Colleges were grouped according to which and how many of the six relationships applied to the college. The nature and strength of denominational control did not appear to have any bearing on the scores for the scholarship scale. However, the colleges with the strongest legal and spiritual ties demonstrated higher scores on the community, propriety, and practicality scales. Pace(1972) concluded:

Whether one sorts the colleges into mainline versus evangelical-fundamentalist groups or classifies them along some index of closeness of association with a denomination, regardless of which denomination, one finds that the more firmly and zealously a college is related to a church the more clearly it emerges as a distictive college environment. And this distinctiveness is defined by uniformly higher scores on the characteristics labeled community, propriety, and practicality. Moreover, on all five measures, the environments of mainline denominational colleges show a greater diversity or range of difference than those of the evangelical-fundamentalist colleges. With respect to most of these dimensions, the colleges most 
loosely connected with the church are also more diverse, or less homogeneous, than ones closely tied to the church (p. 36).

A somewhat different approach was taken by Hobbs and Meeth (1980) to describe the common natures and the dissimilarities of the Christian colleges. They identified two fundamental dimensions from which to examine the colleges: (1) the nature of the denominational connection and (2) both the nature and extent of their emphases on academic and behavioral concerns (p. 11).

Four categories of denominational connections were defined.

1. The historically denominational college: those colleges that are almost, but not quite completely separated from the sponsoring church.

2. The denomination-related college: those colleges sponsored by or affiliated with a particular denomination. 3. The college-of-the-denomination: those colleges that exist to educate the denomination members specifically, the intellectual leaders of the denomination.

4. The non-denominational college: those colleges that have no operative connection with a denomination but continue to espouse a Christian purpose.

The second institutional dimension is concerned with what is the primary concern of the college--academic matters or personal and interpersonal characteristics 
dealing with lifestyle and morals. Hobbs and Meeth (1980) recognized that it was not all one or the other, but rather the degree to which one was emphasized over the other. The academic concerns were found to be expressed through a secularized program, through the juxtaposition of faith and learning, or through the integration of faith and learning. Two-thirds of the colleges were found to focus primarily on behavioral concerns, with the other one-third on academic concerns. The majority of colleges that stressed behavioral matters emphasized personal piety over social responsibility. Of the one-third of the colleges that stressed academic matters over behavioral, 53 percent juxtaposed faith and learning, 35 percent had a completely secularized program, while the few remaining colleges attempted to integrate faith and learning.

The interaction of denominational connections with these findings provided only a few conclusions. The denomination-related colleges and the historically denominational colleges tended to emphasize social responsibility. However,

the relationship of these colleges to their denominations is often unimportant to their educational missions. . . . the patterns revealed in the data are genuine and they are instructive. But they are so few in number and so limited in their coverage that their chief contribution is to document the basic finding: Christian colleges are exceedingly diverse (pp. 37,40$)$. 
Summary

The category "liberal arts colleges" includes a wide range of institutions that may have very little in common with each other. Enviromental differences exist among: Catholic, Protestant, and nonsectarian colleges; between colleges high on selectivity and size, and low on selectivity and size; and between evangelicalfundamentalist colleges and mainline denominational colleges.

A limitation of the studies in this section is the lack of data on the interaction of size with the environment. Astin and Lee (1972) found that the Catholic colleges had a more formal environment than the Protestant colleges. It is possible that the larger average size of the Catholic college's enrollment may lead to this greater degree of formality. Pace (1972) found the evangelicalfundamentalist colleges to have higher scores on the propriety, practicality, and community scales than their mainline-denominational counterparts. He also found a positive correlation between strength of church ties and these same three scales. 


\section{The Institutional Functioning Inventory}

The Institutional Functioning Inventory (IFI) grew out of a study of institutional vitality supported by the Kettering Foundation and developed at Educational Testing Service by Peterson, Centra, Hartnett, and Linn (1970). The purpose of the IFI is to "provide a means by which a college or university can describe itself in terms of a number of characteristics judged to be of importance in American higher education ( $p .1$ )." It is also intended for use in self-studies by individual institutions for systematically evaluating various components of the college's environment with reference to institutional missions and goals. Of particular significance for this study, the authors stressed the research application of this instrument.

Students of higher education may find the IFI useful in multicollege studies that seek a better understanding of the varying roles of different colleges. Most previous instruments designed to assess college environments have relied mainly on student reporters. An instrument aimed at recording faculty views may, therefore, add considerably to what is now known. Furthermore, many multicollege studies are conducted by consortia of colleges with common concerns and objectives. Intercollege comparisons of IFI data among the group may serve to reveal differences not otherwise apparent (p. 13). 


\section{Scales and Format}

The IFI employs the collective perception technique and is intended primarily for use with faculty. It contains 132 questions using two types of format. The first is a relatively objective statement to which the respondent answers Yes, No, or Do Not know (e.g., "there are no written rules regarding student dress"). The second format asks for an opinion and a response of strongly Agree, Agree, Disagree, or Strongly Disagree. For either response format, the keyed response is given a score of one.

The 132 questions are evenly divided among 11 dimensions or scales, with a possible high score of 12 on any scale. Individual scores are averaged to provide an institutional mean. A brief description of the 11 scales follows.

(IAE) Intellectual-Aesthetic Extracurriculum: the extent to which activities and opportunities for intellectual and aesthetic stimulation are available outside the classroom. (F) Freedom: The extent of academic freedom for faculty and students as well as freedom in their personal lives for all individuals in the campus community.

(HD) Human Diversity: the degree to which the 
faculty and student body are heterogeneous in their backgrounds and present attitudes. (IS) Concern for Improvement of Society: the desire among people at the institution to apply their knowledge and skills in solving social problems and prompting social change in America. (UL) Concern for Undergraduate Learning: the degree to which the college--in its structure, function, and professional commitment of faculty-emphasize undergraduate teaching and learning. (DG) Democratic Governance: the extent to which individuals in the campus community who are directly affected by a decision have the opportunity to participate in making the decision. (MLN) Meeting Local Needs: institutional emphasis on providing educational and cultural opportunities for all adults in the surrounding community .

(SP) Self-Study and Planring: the importance college leaders attach to continuous long-range planning for the total institution, and to institutional research needed in formulating and revising plans.

(AK) Concern for Advancing Knowledge: the degree to which the institution--in its structure, 
function, and professional commitment of faculty-emphasizes research and scholarship aimed at extending the scope of human knowledge. (CI) Concern for Innovation: the strength of institutional commitment to experimentation with new ideas for educational practice. (IE) Institutional Esprit: the level of morale and sense of shared purposes among faculty and administrators (Peterson, et al., 1970, pp. 1-2). In 1978 the IFI was revised with necessary updating of the language. At the same time, new comparative data were developed providing item responses and scale scores for faculty and administrators. Separate reports are available for public universities, private universities, four-year state colleges, liberal arts colleges, community colleges, and private junior colleges. Normative data for the structural classification liberal arts colleges were derived from 4,675 faculty and 1,202 administrators from 96 institutions. These institutions ranged in enrollment size from 208 students to 13,265, with an average of 1561 .

Reliability and Validity

Since the IFI is based on the concept of group measure rather than an individual measure, reliability has been reported in terms of group scores. The coefficient 
alpha reliabilities for the 11 scales are reported in Table II and have been judged adequate by Dressel and Lunneborg (Buros, 1972).

Table II

COEFFICIENT ALPHA RELIABILITIES

\begin{tabular}{lcc}
\hline Scale & Faculty & Administrators \\
\hline IAE & .88 & .88 \\
F & .90 & .86 \\
HD & .90 & .86 \\
IS & .95 & .92 \\
UI & .92 & .88 \\
DG & .96 & .93 \\
MLN & .92 & .89 \\
SP & .86 & .83 \\
AK & .96 & .94 \\
CI & .92 & .87 \\
IE & .92 & .90 \\
\hline Note: From Peterson, et al., 1970, p. 16.
\end{tabular}

Validity of the IFI was established by correlating faculty responses to relevant institutional data, student perceptions of their colleges using CUES, and a national study of student protest. Dressel found "commendable effort" in these attempts and detailed validation results for each scale are included in the IFI preliminary Technical Manual (Peterson, et.al., 1970). 
In addition, a multigroup-multiscale matrix was used for validation. The correlations of administrators, faculty, and student responses were reported in the Preliminary Technical Manual and later interpreted by Hartnett and Centra (1974). "The most basic finding suggested. - a good deal of consensus between the three groups in their responses to the scales (p. 163)." They concluded that "the general nature of the institutional environment was perceived relatively uniformly by most members of the acadenic community (p. 168)."

\section{Conclusions}

The traditional structural classifications of colleges and universities focus on easily observable institutional characteristics, but are simplistic approaches to understanding the experiential nature of the college and university. The college environment as a hypothetical construct is recognized as a valid endeavor for research and has resulted in numerous instruments for that purpose. Studies with these instruments have shown that institutions within these structural classifications do exhibit certain tendencies regarding environmental dimensions, but they have also shown that the generalizations possible are very broad, with a wide variance within most classifications. 
The category "liberal arts colleges" has been found to be problematic for these very reasons. Enrollment size, religious affiliation, selectivity in admissions, strength of church relations, and other factors have been found to influence the environments of colleges within this group. Such diversity has been found that the value of such a category has been questioned. Consequently, our understanding of the many subgroups of colleges within this category is incomplete. This understanding is necessary for the fulfillment of institutional missions and for the preservation of plurality within American higher education. The Institutional Functioning Inventory assesses 11 environmental dimensions that will allow a description of the environments at the colleges of interest. The distinctive advantage the IFI has over other environmental assessment instruments is that nationally normed data exist by structural classifications that will allow comparisons in answer to a major research question of this study. 
CHAPTER III

\section{RESEARCH DESIGN AND METHODOLOGY}

Taxonomies of colleges and universities usually classify the small liberal arts Christian colleges under the heading of "liberal arts colleges," or "Protestant colleges." The purpose of this study was to determine if these colleges provide college environments distinctive from the traditional classifications of colleges and universities. To make this determination an ex post facto design was selected. The design included a method for comparing environmental characteristics of these Christian colleges with those characteristics of colleges making up the traditional classifications. This comparison has been simplified by the availability of summary statistics from the Institutional Functioning Inventory (IFI), which is based on a large national normative sample of colleges classified in the traditional manner. Therefore, to make the comparison with the available normative data, environmental measures were needed on a sample of small liberal arts Christian colleges. 


\section{Sampling Procedures and Considerations}

The following criteria were used for selecting colleges for the sample:

1. A statement in the college catalog of liberal arts emphasis;

2. A statement in the college catalog that a Christian environment or that Christian education is of major importance or a major purpose of the college;

3. An enrollment of under 500 students, FTE;

4. Accreditation by a regional accrediting agency; and

5. Coeducational.

A search of the College Blue Book revealed $3 I$ private four-year colleges in the Pacific Northwest (Idaho, Oregon, and Washington). Further investigation showed that of these 31 colleges, six colleges located in Oregon met the above criteria. They are:

1. Judson Baptist College -- The Dalles, Oregon;

2. Columbia Christian College -- Portland, Oregon;

3. Concordia College -- Portland, Oregon;

4. Warner Pacific College -- Portland, Oregon;

5. Western Baptist College -- Salem, Oregon;

6. Northwest Christian College -- Eugene, Oregon. In addition, it was determined that none of these six 
colleges was included in the IFI national norming sample of 96 liberal arts colleges. Enrollments ranged from 210 to 386 students, with an average of 268 . Because of the small sizes of these institutions, many individuals fulfill several roles, making exact numbers of faculty and administrators difficult to determine. In some cases, positions that normally are classified as staff positions in larger institutions involve some teaching responsibilities--sometimes as much as two or three classes per quarter. Generally, however, these institutions employ approximately 20 to 28 people in professional positions that qualify under the definitions employed in this study.

\section{Instrumentation}

The Institutional Functioning Inventory (IFI) was selected for this study for the following reasons.

1. The IFI is the most recently developed instrument for environmental assessment, and the only tool with appropriate normative data.

2. It contains national norms for seven classifications of colleges.

3. It provides eleven scales that include the major dimensions of the environment that are found on most other instruments.

The format of the IFI provides collective mean 
scores for each institution on each environmental dimension, along with a total sample mean for each dimension. These means may also be broken down by faculty and administrator responses. This scoring format allows for comparison of institutions, for a comparison of faculty and administrator responses, and for a comparison of the total sample to the normative data.

\section{Data Gathering Procedures}

Presidents or Deans of the six colleges were contacted and asked for institutional cooperation and participation in the study. Cooperation was received from all institutions, and the data were collected during the spring quarter (April and May), 1983. Five of the six administrators consented to have the IFI administered to faculty and administrators in a group setting at each of the individual colleges. At these five colleges, the researcher met with the faculty and administrators and explained the nature of the research, the directions for completing the IFI, and the confidential nature of the responses. At four of these colleges the respondents were given up to 45 minutes to complete the IFI, after which the IFI and answer sheets were collected. At no time did the colleges have access to these completed answer sheets. At the fifth college less time was available for completion. 
In this instance respondents completed the IFI at a later time. A college administrator collected the completed forms and returned them to the researcher. To help insure a satisfactory sample size, those faculty and administrators who were unable to attend the group meeting were assessed on an individual basis. IFI question booklets, answer sheets, and directions were left with the college Dean to distribute, collect, and return. This resulted in an increased sample size of approximately 20 percent.

At the sixth college access to a faculty meeting or similar group setting was not available. In this instance the Dean distributed the IFI question booklets, answer sheets, and directions to faculty and administrators, collected the materials after completion, and returned them to the researcher.

\section{Statistical Design and Hypotheses}

In addressing the research questions pertaining to the common and differing perceptions of the environments among the sample colleges, a multivariate analysis of variance with SPSS was performed, using the participating colleges as the levels of the independent variable and the 11 scale values of the IFI as the dependent variables. The statistical hypothesis for this test was that the vectors of means for the various populations are equal. 
Alpha was set at .05 for this analysis, using Hotelling's test as the statistic. In the event of the rejection of the statistical hypothesis in the multivariate analysis of variance, it was decided that a univariate analysis of variance would be performed on each scale, with alpha set at .05 . For each univariate test, the statistical hypothesis was that all population means are equal $\left(\mathrm{H}_{0}: \mu_{1}=\mu_{2}=\mu_{3}=\mu_{4}=\mu_{5}=\mu_{6}\right)$. Therefore, the research hypothesis for each scale was that not all population means are equal. With the rejection of a univariate statistical hypothesis for a scale, schaffé's test for all pair-wise mean comparisons was performed on that scale. The general model for the hypotheses were:

$$
\begin{array}{ll}
\mathrm{H}_{0}: \mu_{1}=\mu_{2} & \text { (Statistical Hypothesis) } \\
\mathrm{H}_{1}: \mu_{1}>\mu_{2} & \text { (Research Hypothesis) } \\
\mathrm{H}_{3}: \mu_{1}<\mu_{2} & \text { (Research Hypothesis) }
\end{array}
$$

Alpha was also set at .05 for each of these tests.

A second multivariate analysis of variance was performed using faculty and administrator status as the levels of the independent variable and the 11 scale values of the IFI as the dependent variables. The statistical hypothesis for this test was that the vectors of means for the two populations are equal. Alpha was set at .05 for this analysis, again using Hotelling's test as the 
statistic. In the event of the rejection of the statistical hypothesis in the multivariate analysis of variance, it was decided that a univariate analysis of variance would be performed on each scale, with alpha at .05. For each univariate test, the statistical hypothesis was that all population means are equal $\left(H_{0}: \mu_{1}=\mu_{2}=\mu_{3}=\right.$ $\left.\mu_{4}=\mu_{5}=\mu_{6}\right)$. Therefore, the research hypothesis for each scale was that not all population means are equal. In answer to the research question that pertained to a comparison of the perceptions of the faculty and administrators of small liberal arts Christian colleges to the perceptions of the faculty and administrators at liberal arts colleges and at four-year state colleges, the statistic $\underline{z}$, sometimes referred to as the Critical Ratio (Clarke, Coladarci, \& Caffrey, 1965), was employed. Eleven tests for significance were run, comparing the sample colleges to the liberal arts colleges on the 11 scales of the IFI, using the normative sample as a population. A second set of 11 tests were run comparing the sample colleges to the four-year state colleges on the 11 scales of the IFI, again using the normative sample as a population for the analysis. The hypotheses for the resulting 22 tests took the general form: 


$$
\begin{aligned}
& \mathrm{H}_{0}: \mu_{1}=\mu_{2} \text { (Statistical Hypothesis) } \\
& \mathrm{H}_{1}: \mu_{1}>\mu_{2} \text { (Research Hypothesis) } \\
& \mathrm{H}_{2}: \mu_{1}<\mu_{2} \text { (Research Hypothesis) } \\
& \text { Alpha was set at .05 for all tests. }
\end{aligned}
$$


CHAPTER IV

\section{DATA PRESENTATION AND FINDINGS}

The purpose of this study was to determine if the small liberal arts Christian college provides a distinctive college environment, apart from the traditional classifications of colleges and universities. The research questions centered around the nature and the common and differing perceptions of the environment at these colleges, and how the perceptions of these environments, as a whole, compare to the perceptions of the environments at liberal arts and four-year state colleges. Results of the research are presented in three major sections: (1) scale scores on the IFI by institution; (2) faculty and administrator responses, along with total sample means for the 11 scales of the IFI; and (3) a comparison of the total sample means on the IFI with the normative data for liberal arts and four-year state colleges. Each section includes descriptive data, followed by the findings of the various inferential statistical tests employed. 


\section{Analysis by Institution}

In this section are presented frequency distributions, means, and standard deviations for all institutions on each scale, and the results of hypothesis testing concerning differences among institutions.

\section{Scale Score by Institution}

Frequency distributions, institutional means, standard deviations, and number of responses for the 11 scales of the IFI are presented in Tables III to XIII. Because of the small number of administrators per college, only the combined responses of the faculty and administrators for each college were tabulated.

The number of responses per institution ranged from 13 to 27 , representing an approximate 65 to 100 percent of the potential respondents per institution. Scale score means ranged as follows:

Intellectual-Aesthetic Extracurriculum (IAE) -2.50 to 4.94 ;

Freedom (F) -- 3.04 to 6.20 ;

Human Diversity (HD) -- 2.00 to 5.67 ;

Concern for the Improvement of society (IS) --3.35 to 6.81 ;

Concern for Undergraduate Learning (IL) -- 8.64 to 9.77;

Democratic Governance (DG) -- 4.96 to 7.94;

Meeting Local Needs (MLN) -- 6.40 to 8.26 ;

Self-Study and Planning (SP) -- 4.21 to 9.15; 
Concern for the Advancement of Knowledge (AK) -1.04 to 1.63 ;

Concern for Innovation (CI)-- 5.33 to 7.32 ; and

Institutional Esprit (IE)-- 8.92 to 10.56 .

Generally, scores were low on the environmental

dimensions of Intellectual-Aesthetic Extracurriculum (IAE),

Human Diversity (HD), and Concern for the Advancement of

Knowledge $(A K)$; and moderately low on Freedom $(F)$ and

Concern for the Improvement of Society (IS). High

scores were found on Concern for Undergraduate Learning

(UL) and Institutional Esprit (IE). Scores on the

remaining five scales fell in the middle ranges. 
TABLE III

FREQUENCY DISTRIBUTIONS BY INSTITUTION

(IAE) INTELLECTUAL-AESTHETIC EXTRACURRICULUM

\begin{tabular}{|c|c|c|c|c|c|c|}
\hline \multirow{2}{*}{$\begin{array}{l}\text { Scale } \\
\text { Score }\end{array}$} & \multicolumn{6}{|c|}{ College } \\
\hline & 1 & 2 & 3 & 4 & 5 & 6 \\
\hline \multicolumn{7}{|l|}{12} \\
\hline \multicolumn{7}{|l|}{11} \\
\hline 10 & & & 1 & & & \\
\hline 9 & & & & 2 & & \\
\hline 8 & 1 & & 2 & 1 & 2 & 1 \\
\hline 7 & & 1 & 3 & 2 & & \\
\hline 6 & & & 2 & 1 & 3 & \\
\hline 5 & 3 & 4 & 2 & 3 & 6 & 4 \\
\hline 4 & 1 & 7 & 3 & 4 & 3 & 2 \\
\hline 3 & 5 & 3 & 2 & 2 & 2 & 2 \\
\hline 2 & 8 & 4 & 7 & 4 & 1 & 3 \\
\hline 1 & 2 & 5 & 5 & 1 & & 1 \\
\hline \multirow[t]{2}{*}{0} & 4 & 1 & & & & \\
\hline & \multicolumn{6}{|c|}{ Summary Statistics } \\
\hline$n$ & 24 & 25 & 27 & 20 & 17 & 13 \\
\hline Mean & 2.50 & 3.08 & 3.92 & 4.60 & 4.94 & 3.76 \\
\hline S.D. & 1.91 & 1.73 & 2.63 & 2.41 & 1.60 & 1.88 \\
\hline
\end{tabular}


TABLE IV

FREQUENCY DISTRIBUTIONS BY INSTITUTION

(F) FREEDOM

\begin{tabular}{|c|c|c|c|c|c|c|}
\hline \multirow{2}{*}{$\begin{array}{l}\text { Scale } \\
\text { Score }\end{array}$} & \multicolumn{6}{|c|}{ College } \\
\hline & $I$ & 2 & 3 & 4 & 5 & 6 \\
\hline \multicolumn{7}{|l|}{12} \\
\hline 11 & & & 1 & & & \\
\hline 10 & & & & & 1 & \\
\hline 9 & & & 3 & 3 & & 1 \\
\hline 8 & & & & 3 & & \\
\hline 7 & & 1 & 5 & 4 & 3 & 2 \\
\hline 6 & 1 & 1 & 3 & 4 & 4 & 1 \\
\hline 5 & 5 & 5 & 3 & 1 & 2 & 3 \\
\hline 4 & 2 & 3 & 4 & 1 & 4 & \\
\hline 3 & 7 & 9 & 2 & 4 & 2 & 3 \\
\hline 2 & 4 & 3 & 3 & & 1 & 2 \\
\hline 1 & 5 & 3 & 2 & & & 1 \\
\hline \multirow[t]{2}{*}{0} & & & 1 & & & \\
\hline & \multicolumn{6}{|c|}{ Summary statistics } \\
\hline$n$ & 24 & 25 & 27 & 20 & 17 & 13 \\
\hline Mean & 3.04 & 3.44 & 5.03 & 6.20 & 5.24 & 4.46 \\
\hline S.D. & 1.55 & 1.56 & 2.79 & 2.09 & 1.95 & 2.37 \\
\hline
\end{tabular}




\section{TABLE V}

FREQUENCY DISTRIBUTIONS BY INSTITUTION

(HD) HUMAN DIVERSITY

\begin{tabular}{|c|c|c|c|c|c|c|}
\hline \multirow{2}{*}{$\begin{array}{l}\text { Scale } \\
\text { Score }\end{array}$} & \multicolumn{6}{|c|}{ College } \\
\hline & 1 & 2 & 3 & 4 & 5 & 6 \\
\hline \multicolumn{7}{|l|}{12} \\
\hline 11 & & & & 1 & & \\
\hline \multicolumn{7}{|l|}{10} \\
\hline 9 & & & 2 & 1 & 1 & \\
\hline 8 & & & 5 & 1 & & 2 \\
\hline 7 & & & 2 & 1 & & \\
\hline 6 & & 2 & 5 & 4 & 3 & 1 \\
\hline 5 & & & 5 & 3 & 2 & 2 \\
\hline 4 & 2 & 4 & 3 & 4 & 2 & 1 \\
\hline 3 & 5 & 6 & 4 & 2 & 4 & 4 \\
\hline 2 & 10 & 8 & 1 & 1 & 4 & 2 \\
\hline 1 & 5 & 5 & & 2 & 1 & 1 \\
\hline \multirow[t]{2}{*}{0} & 2 & & & & & \\
\hline & \multicolumn{6}{|c|}{ Summary statistics } \\
\hline$n$ & 24 & 25 & 27 & 20 & 17 & 13 \\
\hline Mean & 2.00 & 2.68 & 5.67 & 5.00 & 3.88 & 4.08 \\
\hline S.D. & 1.06 & 1.41 & 2.02 & 2.53 & 2.06 & 2.22 \\
\hline
\end{tabular}


TABLE VI

FREQUENCY DISTRIBUTIONS BY INSTITUTION

(IS) CONCERN FOR THE IMPROVEMENT OF SOCIETY

\begin{tabular}{|c|c|c|c|c|c|c|}
\hline \multirow{2}{*}{$\begin{array}{l}\text { Scale } \\
\text { Score }\end{array}$} & \multicolumn{6}{|c|}{ College } \\
\hline & 1 & 2 & 3 & $\overline{4}$ & 5 & 6 \\
\hline \multicolumn{7}{|l|}{12} \\
\hline 11 & & & 2 & & & \\
\hline 10 & & & 4 & & & \\
\hline 9 & 2 & & 1 & & & \\
\hline 8 & & 2 & 4 & 1 & & \\
\hline 7 & 4 & 3 & 6 & 1 & 1 & 1 \\
\hline 6 & 3 & 1 & 3 & 3 & 3 & \\
\hline 5 & 1 & 1 & 2 & 2 & 5 & 3 \\
\hline 4 & 2 & 5 & 1 & & 2 & 3 \\
\hline 3 & 5 & 2 & 1 & 6 & 5 & 4 \\
\hline 2 & & 6 & 1 & 2 & & 2 \\
\hline 1 & 3 & 4 & 2 & 2 & 1 & \\
\hline \multirow[t]{2}{*}{0} & 4 & 1 & & 3 & & \\
\hline & \multicolumn{6}{|c|}{ Summary statistics } \\
\hline$n$ & 24 & 25 & 27 & 20 & 17 & 13 \\
\hline Mean & 3.96 & 3.60 & 6.81 & 3.35 & 4.35 & 3.85 \\
\hline S.D. & 2.91 & 2.40 & 2.83 & 2.41 & 1.54 & 1.41 \\
\hline
\end{tabular}


TABLE VII

FREQUENCY DISTRIBUTIONS BY INSTITUTION (UL) CONCERN FOR UNDERGRADUATE LEARNING

\begin{tabular}{|c|c|c|c|c|c|c|}
\hline \multirow{2}{*}{$\begin{array}{l}\text { Scale } \\
\text { Score }\end{array}$} & \multicolumn{6}{|c|}{ College } \\
\hline & 1 & 2 & 3 & 4 & 5 & 6 \\
\hline 12 & 1 & & 2 & 1 & & 1 \\
\hline 11 & 5 & 1 & 8 & 4 & 1 & 5 \\
\hline 10 & 7 & 5 & 4 & 7 & 3 & 2 \\
\hline 9 & 7 & 11 & 6 & 4 & 7 & 1 \\
\hline 8 & 1 & 2 & 3 & 1 & 3 & 3 \\
\hline 7 & 3 & 4 & 2 & 2 & 1 & 1 \\
\hline 6 & & 2 & 2 & 1 & 2 & \\
\hline \multicolumn{7}{|l|}{5} \\
\hline \multicolumn{7}{|l|}{4} \\
\hline \multicolumn{7}{|l|}{3} \\
\hline \multicolumn{7}{|l|}{2} \\
\hline \multicolumn{7}{|l|}{1} \\
\hline \multicolumn{7}{|l|}{0} \\
\hline \multicolumn{7}{|c|}{ Summary statistics } \\
\hline $\mathrm{n}$ & 24 & 25 & 27 & 20 & 17 & 13 \\
\hline Mean & 9.54 & 8.64 & 9.48 & 9.50 & 8.65 & 9.77 \\
\hline S.D. & 1.35 & 1.32 & 1.72 & 1.54 & 1.37 & 1.59 \\
\hline
\end{tabular}


TAELE VIII

FREQUENCY DISTRIBUTIONS BY INSTITUTION

(DG) DEMOCRATIC GOVERNANCE

\begin{tabular}{|c|c|c|c|c|c|c|}
\hline \multirow{2}{*}{$\begin{array}{l}\text { Scale } \\
\text { score }\end{array}$} & \multicolumn{6}{|c|}{ College } \\
\hline & 1 & 2 & 3 & 4 & 5 & 6 \\
\hline 12 & & & 1 & 1 & 2 & \\
\hline 11 & 1 & 2 & 7 & 1 & 2 & 1 \\
\hline 10 & 1 & 2 & 5 & 4 & 2 & 2 \\
\hline 9 & & 1 & 2 & 2 & 1 & 1 \\
\hline 8 & 3 & 4 & 2 & 1 & 3 & 1 \\
\hline 7 & 1 & 4 & 1 & 2 & 2 & 2 \\
\hline 6 & 2 & 1 & 2 & 2 & 2 & 1 \\
\hline 5 & 7 & 2 & 1 & & 1 & 4 \\
\hline 4 & 2 & 2 & & & & 1 \\
\hline 3 & 3 & 2 & 1 & 2 & 1 & \\
\hline 2 & 1 & 2 & 2 & & 1 & \\
\hline 1 & 1 & 1 & 1 & 5 & & \\
\hline \multirow[t]{2}{*}{0} & 2 & 2 & 2 & & & \\
\hline & \multicolumn{6}{|c|}{ Summary statistics } \\
\hline$n$ & 24 & 25 & 27 & 20 & 17 & 13 \\
\hline Mean & 4.96 & 5.84 & 7.59 & 6.30 & 7.94 & 7.08 \\
\hline S.D. & 2.82 & 3.34 & 3.87 & 3.91 & 2.95 & 2.33 \\
\hline
\end{tabular}


TABLE IX

FREQUENCY DISTRIBUTIONS BY INSTITUTION

(MLN) MEETING LOCAL NEEDS

\begin{tabular}{|c|c|c|c|c|c|c|}
\hline \multirow{2}{*}{$\begin{array}{l}\text { Scale } \\
\text { Score }\end{array}$} & \multicolumn{6}{|c|}{ College } \\
\hline & 1 & 2 & 3 & 4 & 5 & 6 \\
\hline 12 & 1 & & 1 & & & \\
\hline 11 & 1 & 2 & & 2 & & 2 \\
\hline 10 & & 1 & 8 & & 1 & 1 \\
\hline 9 & 3 & 1 & 5 & 2 & 1 & 1 \\
\hline 8 & 4 & 6 & 3 & 6 & 4 & 1 \\
\hline 7 & 3 & 2 & 7 & 8 & 5 & 4 \\
\hline 6 & 5 & 4 & 1 & 2 & 3 & 2 \\
\hline 5 & 6 & 3 & & & 1 & 2 \\
\hline 4 & 1 & 2 & 1 & & 2 & \\
\hline 3 & & 2 & 1 & & & \\
\hline 2 & & 2 & & & & \\
\hline \multicolumn{7}{|l|}{1} \\
\hline \multicolumn{7}{|l|}{0} \\
\hline \multicolumn{7}{|c|}{ Summary statistics } \\
\hline$n$ & 24 & 25 & 27 & 20 & 17 & 13 \\
\hline Mean & 6.96 & 6.40 & 8.26 & 7.80 & 6.88 & 7.62 \\
\hline S.D. & 2.03 & 2.57 & 1.99 & 1.36 & 1.62 & 2.06 \\
\hline
\end{tabular}


TABLE X

FREQUENCY DISTRIBUTIONS BY INSTITUTION

(SP) SELF-STUDY AND PLANNING

\begin{tabular}{|c|c|c|c|c|c|c|}
\hline \multirow{2}{*}{$\begin{array}{l}\text { Scale } \\
\text { Score }\end{array}$} & \multicolumn{6}{|c|}{ College } \\
\hline & 1 & 2 & 3 & $\overline{4}$ & 5 & 6 \\
\hline 12 & & 1 & & & & \\
\hline 11 & & 5 & 5 & 3 & 4 & \\
\hline 10 & & 1 & 11 & 7 & 3 & \\
\hline 9 & & 1 & 3 & 2 & 2 & 2 \\
\hline 8 & & 2 & 5 & 4 & 1 & 1 \\
\hline 7 & 3 & 3 & & & 1 & 2 \\
\hline 6 & 5 & 3 & 2 & & 2 & 2 \\
\hline 5 & 4 & 4 & & 3 & 2 & 5 \\
\hline 4 & 2 & 5 & & & 2 & \\
\hline 3 & 2 & & 1 & 1 & & \\
\hline 2 & 8 & & & & & \\
\hline \multicolumn{7}{|l|}{1} \\
\hline \multirow[t]{2}{*}{0} & & & & & & 1 \\
\hline & \multicolumn{6}{|c|}{ Summary statistics } \\
\hline$n$ & 24 & 25 & 27 & 20 & 17 & 13 \\
\hline Mean & 4.21 & 7.24 & 9.15 & 8.55 & 8.06 & 5.92 \\
\hline S.D. & 1.91 & 2.76 & 1.85 & 2.33 & 2.61 & 2.33 \\
\hline
\end{tabular}


TABLE XI

FREQUENCY DISTRIBUTIONS BY INSTITUTION

(AK) CONCERN FOR THE ADVANCEMENT OF KNOWLEDGE

\begin{tabular}{lllllll}
\hline Scale & \multicolumn{6}{c}{ College } \\
\cline { 2 - 7 } Score & 1 & 2 & 3 & 4 & 5 & 6 \\
\hline
\end{tabular}

12

II

10

9

8

7

1

6

1

\begin{tabular}{ccccccc}
5 & & & 1 & & & \\
4 & & 1 & 3 & 2 & & \\
3 & 2 & 4 & 2 & 3 & & 2 \\
2 & 5 & 7 & 3 & 4 & 5 & 3 \\
1 & 9 & 8 & 8 & 6 & 8 & 5 \\
0 & 8 & 5 & 9 & 5 & 3 & 3 \\
\hline n & 24 & 25 & 27 & 20 & 17 & 13 \\
Mean & 1.04 & 1.52 & 1.63 & 1.55 & 1.41 & 1.31 \\
S.D. & 0.95 & 1.12 & 1.84 & 1.32 & 1.37 & 1.03 \\
\hline
\end{tabular}


TABLE XII

FREQUENCY DISTRIBUTIONS BY INSTITUTION

(CI) CONCERN FOR INNOVATION

\begin{tabular}{|c|c|c|c|c|c|c|}
\hline \multirow{2}{*}{$\begin{array}{l}\text { Scale } \\
\text { Score }\end{array}$} & \multicolumn{6}{|c|}{ College } \\
\hline & 1 & 2 & 3 & 4 & 5 & 6 \\
\hline 12 & & 1 & 1 & & & \\
\hline 11 & 1 & 2 & & 2 & & \\
\hline 10 & & 1 & 4 & 1 & 3 & 2 \\
\hline 9 & 1 & 4 & 7 & 3 & 3 & \\
\hline 8 & 2 & 4 & 1 & 3 & 2 & 4 \\
\hline 7 & 4 & 3 & 3 & 2 & 2 & 3 \\
\hline 6 & 2 & 4 & 2 & 4 & 3 & 1 \\
\hline 5 & 6 & 3 & 4 & 4 & 1 & 1 \\
\hline 4 & 3 & 2 & 2 & & & 1 \\
\hline 3 & 1 & 1 & & 1 & & \\
\hline 2 & 3 & & 1 & & 2 & 1 \\
\hline 1 & 1 & & 2 & & 1 & \\
\hline \multicolumn{7}{|l|}{0} \\
\hline \multicolumn{7}{|c|}{ Summary Statistics } \\
\hline$n$ & 24 & 25 & 27 & 20 & 17 & 13 \\
\hline Mean & 5.33 & 7.32 & 6.96 & 7.20 & 6.76 & 6.92 \\
\hline S.D. & 2.43 & 2.36 & 2.93 & 2.19 & 2.88 & 2.25 \\
\hline
\end{tabular}


TABLE XIII

FREQUENCY DISTRIBUTIONS BY INSTITUTION

(IE) INSTITUTIONAL ESPRIT

\begin{tabular}{|c|c|c|c|c|c|c|}
\hline \multirow{2}{*}{$\begin{array}{l}\text { Scale } \\
\text { Score }\end{array}$} & \multicolumn{6}{|c|}{ College } \\
\hline & 1 & 2 & 3 & 4 & 5 & 6 \\
\hline 12 & 4 & 7 & 14 & 7 & 6 & 1 \\
\hline 11 & 4 & 9 & 1 & 5 & 5 & 3 \\
\hline 10 & 3 & 4 & 3 & 2 & 3 & 2 \\
\hline 9 & 4 & 2 & 2 & 2 & & 3 \\
\hline 8 & 2 & 2 & 2 & 3 & 1 & 1 \\
\hline 7 & 3 & 1 & 2 & 1 & 2 & 1 \\
\hline 6 & 3 & & & & & 1 \\
\hline 5 & 1 & & 1 & & & \\
\hline 4 & & & 2 & & & \\
\hline 3 & & & & & & 1 \\
\hline \multicolumn{7}{|l|}{2} \\
\hline \multicolumn{7}{|l|}{1} \\
\hline \multicolumn{7}{|l|}{0} \\
\hline \multicolumn{7}{|c|}{ Summary statistics } \\
\hline$n$ & 24 & 25 & 27 & 20 & 17 & 13 \\
\hline Mean & 9.08 & 10.56 & 10.00 & 10.40 & 10.53 & 8.92 \\
\hline S.D. & 2.20 & 1.42 & 2.65 & 1.67 & 1.70 & 2.47 \\
\hline
\end{tabular}


Institutional Comparisons

A multivariate analysis of variance was performed with the participating colleges as the independent variable and the 11 scales of the IFI as the dependent variables. The $\mathrm{F}$ value for Hotellings' test was 5.42 , which was significant at the .05 level $(\underline{p}<0.0001)$. Therefore, the statistical hypothesis was rejected, and univariate analyses of variance were performed on the 11 dependent variables (see Table XIV). This resulted in the rejection of eight of the eleven statistical hypotheses (IAE, F, FD, IS, DG, MLN, SP, IE), with alpha at .05.

Schaffé's test for all pair-wise mean comparisons at the .05 level failed to find significant differences on three of the eight scales for which the ANOVA had resulted in a rejection of the statistical hypothesis. on the remaining five scales, few patterns emerged from the statistics (see Figure 1). College 1 obtained the lowest means on four of the five scales (IAE,F, HD, SP), and differences are significant between it and one or more colleges on those scales. College 3 has the highest means on three of the five scales (ED, IS, SP), and differences are also significant between it and one or more of the colleges on those scales. While differences were found, ranges were not great on any of the scales, perhaps with the exception of SP. 
TABLE XIV

IFI SCALE SCORE ANALYSIS OF VARIANCE.

BY SAMPLE INSTITUTION

\begin{tabular}{lcc}
\hline Scale & $\underline{F}$ & Probability of \\
\hline IAE & 3.986 & $0.0022^{*}$ \\
$F$ & 7.002 & $0.0000^{*}$ \\
HD & 13.038 & $0.0000^{*}$ \\
IS & 6.864 & $0.0000^{*}$ \\
UL & 2.143 & 0.649 \\
DG & 2.529 & $0.0325 * \star$ \\
MLN & 2.831 & $0.0188 * \star$ \\
SP & 14.684 & $0.0000 *$ \\
AK & 0.599 & 0.7007 \\
CI & 1.912 & 0.0972 \\
IE & 2.375 & $0.0430 \star \star$
\end{tabular}

*Significant at the .05 level.

** Significant at the .05 level, but no significant differences were found at the .05 level using Schaffé's test for all pair-wise mean comparisons. 
(IAE) Intellectual-Aesthetic Extracurriculum

Mean

2.50

3.08

3.93

4.60

4.94

Mean

3.04

3.44

4.46

5.03

5.24

6.20

Mean

2.00

2.68

3.88

4.08

5.00

5.67
3.77

$\begin{array}{cc}\text { College } & 1 \\ 1 & \\ 2 & \\ 6 & \\ 3 & \\ 4 & \\ 5 & \text { * }\end{array}$

(F) Freedom

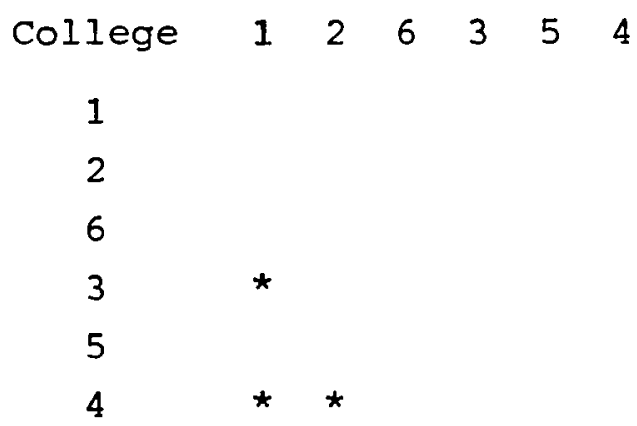

(HD) Human Diversity

Fiqure 1. Significant differences among colleges on the IFI. (*) Denotes pairs of colleges significantly different at the .05 level using Schaffé's pair-wise mean comparisons. 
Fiqure 1. continued

\begin{tabular}{|c|c|c|c|c|c|c|c|}
\hline Mean & College & 4 & 2 & 6 & 1 & 5 & 3 \\
\hline 3.35 & 4 & & & & & & \\
\hline 3.60 & 2 & & & & & & \\
\hline 3.85 & 6 & & & & & & \\
\hline 3.96 & 1 & & & & & & \\
\hline 4.35 & 5 & & & & & & \\
\hline 6.81 & 3 & $\star$ & $\star$ & $\star$ & $\star$ & & \\
\hline
\end{tabular}

(SP) Self-Study and Planning

$\begin{array}{lccccccc}\text { Mean } & \text { College } & 1 & 6 & 2 & 5 & 4 & 3 \\ 4.21 & 1 & & & & & & \\ 5.92 & 6 & & & & & & \\ 7.24 & 2 & \star & & & & & \\ 8.06 & 5 & \star & & & & & \\ 8.55 & 4 & * & & & & & \\ 9.15 & 3 & * & \star & & & & \end{array}$




\section{Analysis by Faculty and Administrator Status}

In this section are presented frequency distributions, means, and standard deviations for faculty responses, administrator responses, and for the total sample, along with the results of the hypothesis testing concerning the differences between the perceptions of the faculty and administrators.

Scale Score by Faculty and Administrator Status

Total sample faculty response distributions, administrator response distributions, and combined response distributions, together with their respective means, standard deviations, and number of responses are presented in Tables XV to XXV. For faculty, the scale means ranged from a low of 1.50 on AK to a high of 9.82 on IE. For administrators, the scale means ranged from a low of 1.24 on AK to a high of 10.30 on IE.

Faculty and Administrator Comparisons

A multivariate analysis of variance was performed with faculty and administrator status as the independent variable and the 11 scales of the IFI as the dependent variables. The $\underline{F}$ value for Hotellings' test was 0.92 , which was not significant at the .05 level $(p=0.525)$. Therefore, the statistical hypothesis was not rejected, and if significant differences exist between the percep- 
tions of the environment by faculty and administrators, they were not detected by this study. These findings are in keeping with the conclusions of Hartnett and Centra (1974), suggesting that with using the IFI, faculty and administrators have a common perception of the environment. 
TABLE XV

TOTAL SAMPLE FREQUENCY DISTRIBUTIONS

(IAE) INTELLECTUAL-AESTHETIC EXTRACURRICULUM

\begin{tabular}{|c|c|c|c|}
\hline $\begin{array}{l}\text { Scale } \\
\text { Score }\end{array}$ & Faculty & Administrators & Total \\
\hline \multicolumn{4}{|l|}{12} \\
\hline \multicolumn{4}{|l|}{11} \\
\hline 10 & 1 & & 1 \\
\hline 9 & 1 & 1 & 2 \\
\hline 8 & 6 & 1 & 7 \\
\hline 7 & 6 & & 6 \\
\hline 6 & 5 & 1 & 6 \\
\hline 5 & 12 & 10 & 22 \\
\hline 4 & 15 & 5 & 20 \\
\hline 3 & 11 & 4 & 16 \\
\hline 2 & 22 & 5 & 27 \\
\hline 1 & 10 & 4 & 14 \\
\hline \multirow[t]{2}{*}{0} & 3 & 2 & 5 \\
\hline & \multicolumn{3}{|c|}{ Summary Siatistics } \\
\hline$n$ & 92 & 33 & $126^{\mathrm{a}}$ \\
\hline Mean & 3.76 & 3.61 & 3.71 \\
\hline$S . D$. & 2.28 & 2.11 & 2.22 \\
\hline
\end{tabular}


TABLE XVI

TOTAL SAMPLE FREQUENCY DISTRIBUTIONS

(F) FREEDCM

\begin{tabular}{|c|c|c|c|}
\hline $\begin{array}{l}\text { Scale } \\
\text { Score }\end{array}$ & Faculty & Administrators & Total \\
\hline \multicolumn{4}{|l|}{12} \\
\hline 11 & 1 & & 1 \\
\hline 10 & & 1 & 1 \\
\hline 9 & 6 & & 7 \\
\hline 8 & 3 & & 3 \\
\hline 7 & 10 & 5 & 15 \\
\hline 6 & 9 & 5 & 14 \\
\hline 5 & 10 & 9 & 19 \\
\hline 4 & 11 & 3 & 14 \\
\hline 3 & 20 & 7 & 27 \\
\hline 2 & 11 & 2 & 13 \\
\hline 1 & 10 & 1 & 11 \\
\hline \multirow[t]{2}{*}{0} & 1 & & 1 \\
\hline & & summary statistics & \\
\hline$n$ & 92 & 33 & $126^{a}$ \\
\hline Mean & 4.34 & 4.79 & $4 \cdot 49$ \\
\hline S.D. & 2.44 & 1.88 & 2.34 \\
\hline
\end{tabular}


TABLE XVII

TOTAL SAMPLE FREQUENCY DISTRIBUTIONS

(HD) HUMAN DIVERSITY

\begin{tabular}{|c|c|c|c|}
\hline $\begin{array}{l}\text { Scale } \\
\text { Score }\end{array}$ & Faculty & Administrators & Total \\
\hline \multicolumn{4}{|l|}{12} \\
\hline 11 & 1 & & 1 \\
\hline \multicolumn{4}{|l|}{10} \\
\hline 9 & 3 & & 4 \\
\hline 8 & 5 & 3 & 8 \\
\hline 7 & 3 & & 3 \\
\hline 6 & 12 & 3 & 15 \\
\hline 5 & 8 & 4 & 12 \\
\hline 4 & 10 & 6 & 16 \\
\hline 3 & 20 & 5 & 25 \\
\hline 2 & 18 & 8 & 26 \\
\hline 1 & 11 & 3 & 14 \\
\hline \multirow[t]{2}{*}{0} & 1 & 1 & 2 \\
\hline & \multicolumn{3}{|c|}{ summary statistics } \\
\hline$n$ & 92 & 33 & $126^{\mathrm{a}}$ \\
\hline Mean & 3.89 & 3.64 & 3.87 \\
\hline S.D. & 2.33 & 2.09 & 2.30 \\
\hline
\end{tabular}


TABLE XVIII

TOTAL SAMPLE FREQUENCY DISTRIBUTIONS

(IS) CONCERN FOR TUE IMPROVEMENT OF SOCIETY

\begin{tabular}{|c|c|c|c|}
\hline $\begin{array}{l}\text { Scale } \\
\text { Score }\end{array}$ & Faculty & Admiristrators & Total \\
\hline \multicolumn{4}{|l|}{12} \\
\hline 11 & 2 & & 2 \\
\hline 10 & 2 & 2 & 4 \\
\hline 9 & 2 & 1 & 3 \\
\hline 8 & 6 & 1 & 7 \\
\hline 7 & 12 & 3 & 16 \\
\hline 6 & 11 & 2 & 13 \\
\hline 5 & 9 & 5 & 14 \\
\hline 4 & 11 & 2 & 13 \\
\hline 3 & 15 & 8 & 23 \\
\hline 2 & 8 & 3 & 11 \\
\hline 1 & 7 & 5 & 12 \\
\hline \multirow[t]{2}{*}{0} & 7 & 1 & 8 \\
\hline & \multicolumn{3}{|c|}{ summary statistics } \\
\hline$n$ & 92 & 33 & $126^{\mathrm{a}}$ \\
\hline Mean & 4.51 & 4.18 & 4.44 \\
\hline S.D. & 2.72 & 2.70 & 2.71 \\
\hline
\end{tabular}


TABLE XIX

TOTAL SAMPLE FREQUENCY DISTRIBUTIONS

(UL) CONCERN FOR UNDFRGRADUATE LEARNING

\begin{tabular}{|c|c|c|c|}
\hline $\begin{array}{l}\text { Scale } \\
\text { Score }\end{array}$ & Faculty & Administrators & Total \\
\hline 12 & 3 & 2 & 5 \\
\hline 11 & 19 & 5 & 24 \\
\hline 10 & 19 & 9 & 28 \\
\hline 9 & 22 & 14 & 36 \\
\hline 8 & 11 & 1 & 13 \\
\hline 7 & 12 & 1 & 13 \\
\hline 6 & 6 & 1 & 7 \\
\hline \multicolumn{4}{|l|}{5} \\
\hline \multicolumn{4}{|l|}{4} \\
\hline \multicolumn{4}{|l|}{3} \\
\hline \multicolumn{4}{|l|}{2} \\
\hline \multicolumn{4}{|l|}{1} \\
\hline \multicolumn{4}{|l|}{0} \\
\hline \multicolumn{4}{|c|}{ summary statistics } \\
\hline n & 92 & 33 & $126^{a}$ \\
\hline Mean & 9.14 & 9.58 & 9.25 \\
\hline S.D. & 1.60 & 1.25 & 1.51 \\
\hline
\end{tabular}


TFELE XX

TOTAL SAMPLE FREQUENCY DISTRIBUTIONS

(DG) DEMOCRATIC GOVERNANCE

\begin{tabular}{|c|c|c|c|}
\hline $\begin{array}{l}\text { Scale } \\
\text { Score }\end{array}$ & Faculty & Administrators & Total \\
\hline 12 & 1 & 3 & 4 \\
\hline 11 & 9 & 4 & 14 \\
\hline 10 & 13 & 3 & 16 \\
\hline 9 & 6 & 1 & 7 \\
\hline 8 & 9 & 5 & 14 \\
\hline 7 & 9 & 3 & 12 \\
\hline 6 & 8 & 2 & 10 \\
\hline 5 & 11 & 4 & 15 \\
\hline 4 & 3 & 2 & 5 \\
\hline 3 & 5 & 4 & 9 \\
\hline 2 & 6 & & 6 \\
\hline 1 & 6 & 2 & 8 \\
\hline \multirow[t]{2}{*}{0} & 6 & & 6 \\
\hline & \multicolumn{3}{|c|}{ Summary statistics } \\
\hline$n$ & 92 & 33 & $126^{\mathrm{a}}$ \\
\hline Mean & 6.28 & 7.09 & 6.53 \\
\hline$S . D$. & 3.46 & 3.29 & 3.43 \\
\hline
\end{tabular}


TF.BLE XXI

TOTAL SAMPIE FREQUENCY DISTRIBUTIONS

(MLN) MEETING LOCAL NEEDS

\begin{tabular}{cccc}
\hline $\begin{array}{c}\text { Scale } \\
\text { Score }\end{array}$ & Faculty & Acministrators & Total \\
\hline 12 & 1 & 1 & 2 \\
11 & 6 & 1 & 7 \\
10 & 10 & 1 & 11 \\
9 & 9 & 4 & 13 \\
8 & 18 & 6 & 24 \\
7 & 17 & 11 & 29 \\
6 & 13 & 4 & 17 \\
5 & 9 & 3 & 12 \\
4 & 4 & 2 & 6 \\
3 & 3 & & 3 \\
2 & 2 & & 2 \\
1 & & &
\end{tabular}

\begin{tabular}{cccc}
\hline \multicolumn{3}{c}{ Summary Statistics } \\
\hline $\mathrm{n}$ & 92 & 33 & $126^{\mathrm{a}}$ \\
Mean & 7.33 & 7.30 & 7.32 \\
S.D. & 2.19 & 1.79 & 2.08 \\
& & & \\
\hline administrator-faculty & status lacking for one response
\end{tabular}


TFELE XXII

TOTAL SAMPLE FREQUENCY DISTRIBUTIONS

(SP) SELF-STUDY AND PLANNING

\begin{tabular}{|c|c|c|c|}
\hline $\begin{array}{l}\text { Scale } \\
\text { Score }\end{array}$ & Faculty & Administrators & Total \\
\hline 12 & 1 & & 1 \\
\hline 11 & 13 & 3 & 17 \\
\hline 10 & 14 & 8 & 22 \\
\hline 9 & 7 & 3 & 10 \\
\hline 8 & 11 & 2 & 13 \\
\hline 7 & 6 & 3 & 9 \\
\hline 6 & 10 & 4 & 14 \\
\hline 5 & 11 & 7 & 18 \\
\hline 4 & 9 & & 9 \\
\hline 3 & 3 & 1 & 4 \\
\hline 2 & 6 & 2 & 8 \\
\hline \multicolumn{4}{|l|}{1} \\
\hline \multirow[t]{2}{*}{0} & 1 & & 1 \\
\hline & \multicolumn{3}{|c|}{ summary statistics } \\
\hline $\mathrm{n}$ & 92 & 33 & $126^{\mathrm{a}}$ \\
\hline Mean & 7.17 & 7.36 & 7.25 \\
\hline S.D. & 2.92 & 2.67 & 2.86 \\
\hline
\end{tabular}




\section{TRELE XXIII}

TOTAL SAMPLE FRECUENCY DISTRIBUTIONS

(AK) CONCERN FOR THE ADVANCEMENT OF KNOWLEDGE

\begin{tabular}{|c|c|c|c|}
\hline $\begin{array}{l}\text { Scale } \\
\text { score }\end{array}$ & Faculty & Administrators & Total \\
\hline
\end{tabular}

12

II

10

9

8

$\begin{array}{lll}7 & 1 & 1\end{array}$

611

$\begin{array}{lll}5 & 1 & 1\end{array}$

$\begin{array}{llll}4 & 5 & 1 & 6\end{array}$

$\begin{array}{llll}31 & 2 & 13\end{array}$

$\begin{array}{llll}2 & 19 & 8 & 27\end{array}$

$\begin{array}{llll}1 & 29 & 15 & 44\end{array}$

$\begin{array}{llll}0 & 25 & 7 & 33\end{array}$

\begin{tabular}{cccc}
\hline \multicolumn{3}{c}{ summary statistics } \\
\hline n & 92 & 33 & $126^{\mathrm{a}}$ \\
Mean & 1.50 & 1.24 & 1.42 \\
S.D. & 1.43 & 0.97 & 1.33 \\
& & & \\
\hline a administrator-faculty & status lacking for one response
\end{tabular}


TA.ELE XXIV

\section{TOTAL SAMPLE FREQUENCY DISTRIBUTIONS}

(CI) CONCERN FOR INNOVATION

\begin{tabular}{|c|c|c|c|}
\hline $\begin{array}{l}\text { Scale } \\
\text { Score }\end{array}$ & Faculty & Acministrators & Total \\
\hline 12 & 2 & & 2 \\
\hline 11 & 4 & 1 & 5 \\
\hline 10 & 8 & 3 & 11 \\
\hline 9 & 11 & 6 & 18 \\
\hline 8 & 12 & 4 & 16 \\
\hline 7 & 13 & 4 & 17 \\
\hline 6 & 9 & 7 & 16 \\
\hline 5 & 12 & 7 & 19 \\
\hline 4 & 7 & 1 & 8 \\
\hline 3 & 3 & & 3 \\
\hline 2 & 7 & & 7 \\
\hline 1 & 4 & & 4 \\
\hline \multicolumn{4}{|l|}{0} \\
\hline & \multicolumn{3}{|c|}{ summary statistics } \\
\hline $\mathrm{n}$ & 92 & 33 & $126^{\mathrm{a}}$ \\
\hline Mean & 6.55 & 7.15 & 6.73 \\
\hline$S . D$. & 2.79 & 1.89 & 2.59 \\
\hline
\end{tabular}


TA.ELE XXV

TOTAL SAMPLE FREQUENCY DISTRIBUTIONS

(IE) INSTITUTIONAI ESPRIT

\begin{tabular}{cccc}
\hline $\begin{array}{c}\text { Scale } \\
\text { Score }\end{array}$ & Faculty & Administrators & Total \\
\hline 12 & 24 & 14 & 39 \\
11 & 22 & 5 & 27 \\
10 & 11 & 6 & 17 \\
9 & 12 & 1 & 13 \\
8 & 9 & 2 & 11 \\
7 & 8 & 2 & 10 \\
6 & 1 & 3 & 4 \\
5 & 2 & & 2 \\
4 & 2 & & 2 \\
3 & 1 & & \\
2 & & & \\
1 & & & \\
0 & & & \\
\hline
\end{tabular}

\begin{tabular}{cccc}
\hline \multicolumn{3}{c}{ summary Statistics } \\
\hline $\mathrm{n}$ & 92 & 33 & $126^{\mathrm{a}}$ \\
Mean & 9.82 & 10.30 & 9.96 \\
S.D. & 2.15 & 2.04 & 2.22 \\
& & & \\
\hline a administrator-faculty & status lacking for one response
\end{tabular}




\section{Sample Colleges-Normative Data Comparisons}

When compared to the liberal arts colleges, the sample college means were lower on all scales of the IFI except for Institutional Esprit (see Figure 2). Of particular note are the substantially lower scores on Intellectual-Aesthetic Extracurriculum, Freedom, Human Diversity, and Concern for the Advancement of Knowledge. When compared to the four-year state colleges, the sample colleges scored higher on five of the IFI scales, most notably Concern for Undergraduate Learning and Institutional Esprit (see Figure 3). Notable again are the substantially lower scores on IAE, F, and HD. The results of the IFI scale mean comparisons for sample colleges and liberal arts colleges are presented in Table XXVI. Significant differences at the .05 level were found on eight of the 11 scales. Only on Concern for Undergraduate Learning, Democratic Governance, and Self-Study and Planning were significant differences not found.

Table XXVII presents the results for mean comparisons for the sample colleges and four-year state colleges. Significant differences were found on eight of the 11 scales at the .05 level. On Concern for Improving Society, Meeting Local Needs, and Concern for Innovation no significant differences were found. 


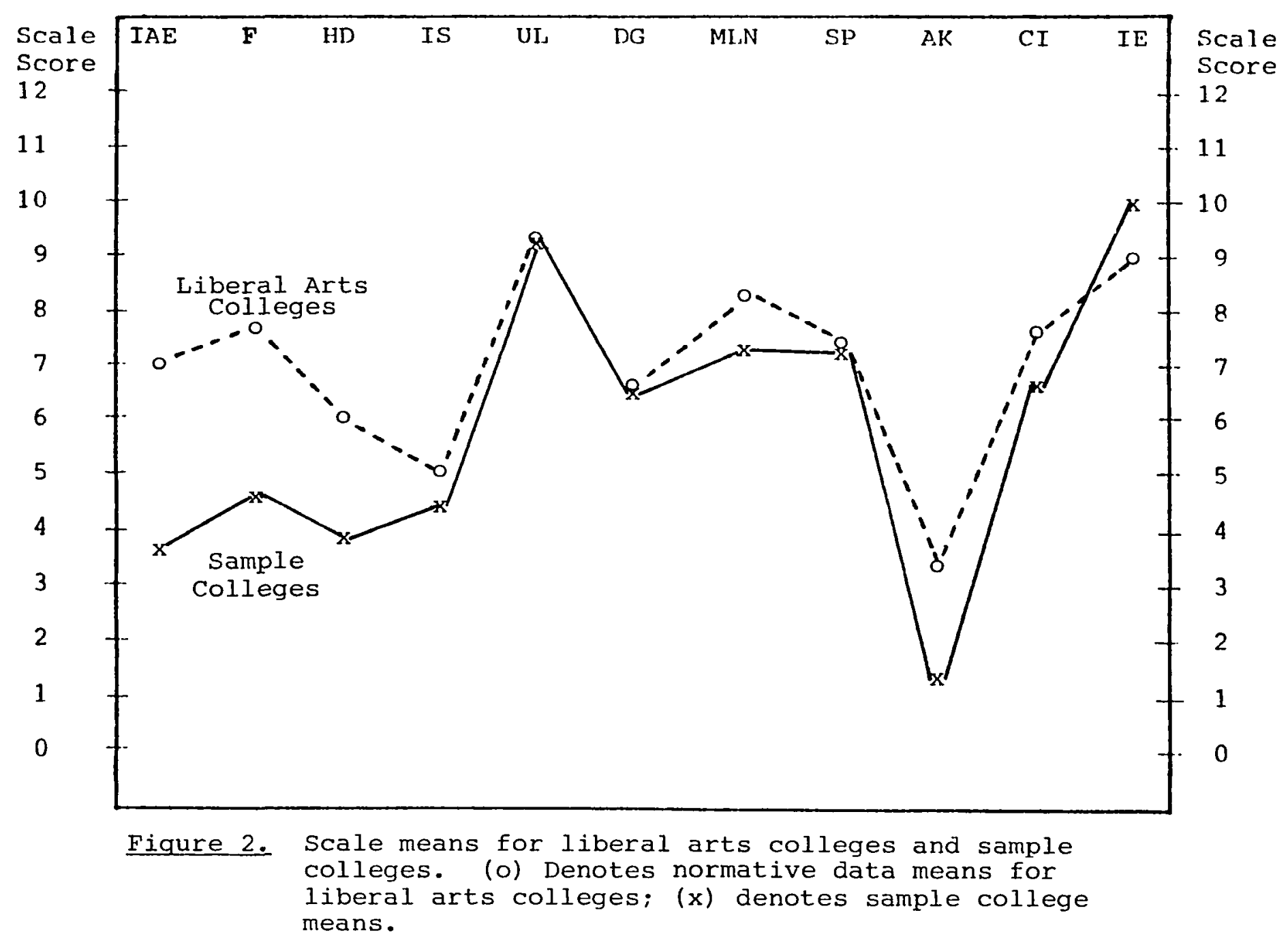


TABLE XXVI

IFI SCALE MEAN COMPARISONS

SAMPLE COLLEGES-IIBERAL ARTS COLLEGES

\begin{tabular}{|c|c|c|c|c|c|}
\hline \multirow{2}{*}{ Scale } & \multicolumn{2}{|c|}{ Liberal Arts } & \multicolumn{2}{|c|}{ Sample } & \multirow{2}{*}{$\underline{z}$} \\
\hline & Mean & S.D. & Mean & S.D. & \\
\hline IAE & 7.04 & 2.88 & 3.71 & 2.22 & $-13 \cdot 0^{\star}$ \\
\hline$F$ & 7.72 & 2.88 & 4.49 & 2.34 & $-12 \cdot 6^{\star}$ \\
\hline $\mathrm{HD}$ & 5.96 & 2.76 & 3.87 & 2.30 & $-8.5^{\star}$ \\
\hline IS & 4.98 & 2.86 & 4.44 & 2.71 & $-2 \cdot 1^{\star}$ \\
\hline UL & 9.34 & 1.92 & 9.25 & 1.52 & -0.5 \\
\hline DG & 6.72 & 3.76 & 6.53 & 3.43 & -0.6 \\
\hline MLN & 8.28 & 2.66 & 7.32 & 2.08 & $-4 \cdot 1^{\star}$ \\
\hline$S P$ & 7.58 & 2.98 & 7.25 & 2.86 & $-1 \cdot 2$ \\
\hline$A K$ & 3.58 & 2.22 & 1.42 & 1.33 & $-10 \cdot 9^{*}$ \\
\hline$C I$ & 7.70 & 2.86 & 6.73 & 2.59 & $-3.8 *$ \\
\hline$I E$ & 9.04 & 3.04 & 9.96 & 2.22 & 3.4 * \\
\hline
\end{tabular}

*Significant at the .05 level. 


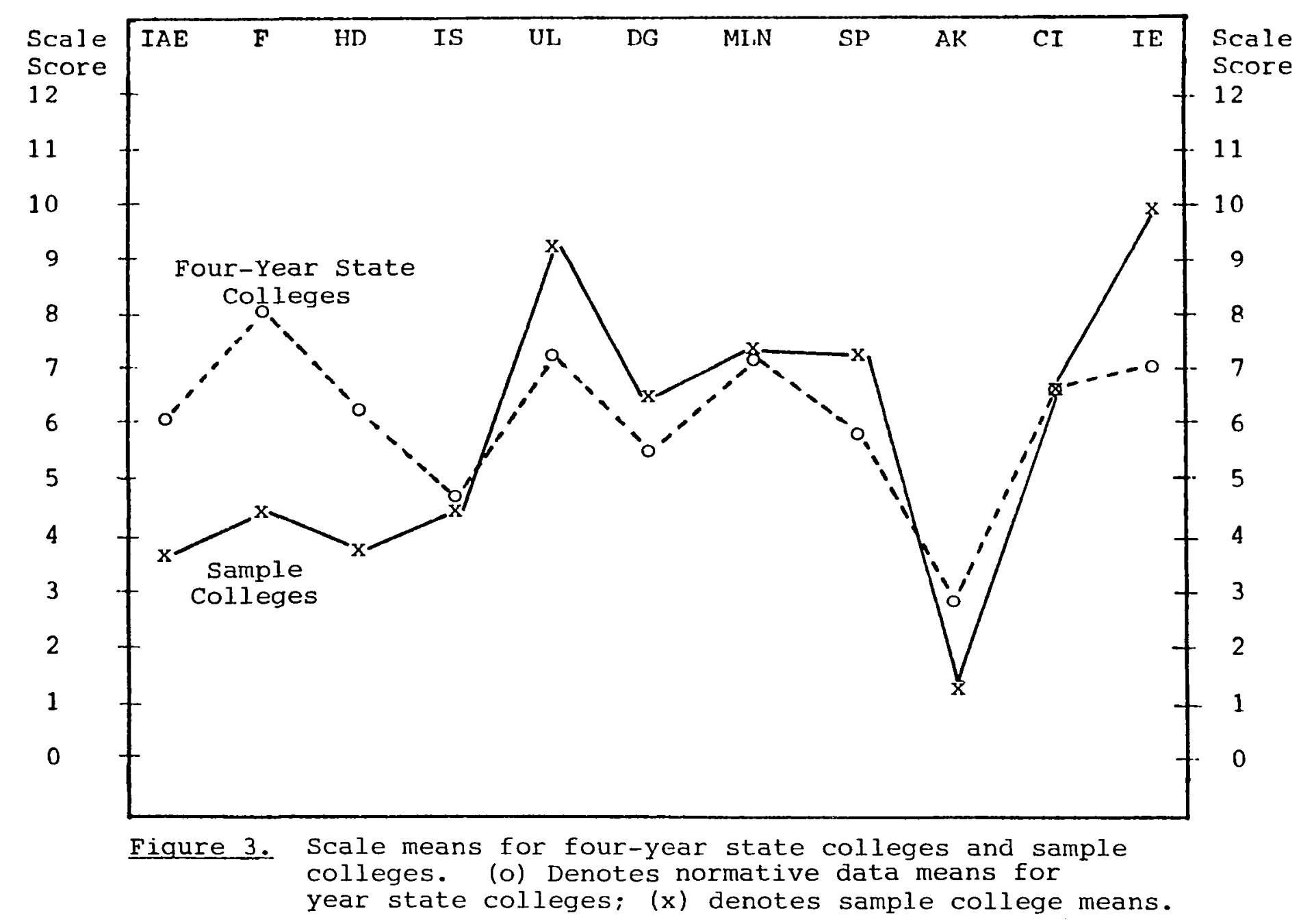


TABLE XXVII

IFI SCALE MEAN COMPARISONS

SAMPLE COLLEGES-FOUR-YEAR STATE COLLEGES

\begin{tabular}{|c|c|c|c|c|c|}
\hline \multirow{2}{*}{ Scale } & \multicolumn{2}{|c|}{ 4-Yr state } & \multicolumn{2}{|c|}{ Sample } & \multirow{2}{*}{$\underline{z}$} \\
\hline & Mean & $S . D$. & Mean & S.n. & \\
\hline IAE & 6.02 & 2.60 & 3.71 & 2.22 & $-10.0 *$ \\
\hline$F$ & 8.03 & 2.64 & 4.49 & 2.34 & $-15.1 *$ \\
\hline HD & 6.22 & 2.47 & 3.87 & 2.30 & $-10.7 *$ \\
\hline IS & 4.70 & 2.70 & 4.44 & 2.71 & $-1 \cdot 1$ \\
\hline UL & 7.28 & 2.62 & 9.25 & 1.52 & $8.4^{\star}$ \\
\hline$D G$ & 5.69 & 3.85 & 6.53 & 3.43 & $2.4 *$ \\
\hline MLN & 7.13 & 2.50 & 7.32 & 2.08 & .9 \\
\hline SP & 5.75 & 3.10 & 7.25 & 2.86 & $5.4 *$ \\
\hline$A K$ & 2.88 & 2.00 & 1.42 & 1.33 & $-8 \cdot 2 *$ \\
\hline$C I$ & 6.70 & 3.18 & 6.73 & 2.59 & .1 \\
\hline IE & 7.09 & 3.47 & 9.96 & 2.22 & $9.3 *$ \\
\hline
\end{tabular}

*Significant at the .05 level. 


\section{Discussion of Findings}

The discussion of the findings in this section focuses on the perceptions of the environments at the sample colleges, a resulting generic environmental description, and comparisons of the sample colleges to the normative data.

Perceptions of the Environments at Sample Colleges

In adaressing the research question pertaining to the common and differing perceptions of the environment at the six sample colleges, a multivariate analysis of variance did find significant differences among institutions, but did not find significant differences between the perceptions of faculty and administrators. Among the colleges, ANOVA tests found significant differences on eight of the 11 IFI scales. The question then arises as to the degree of homogeneity or heterogeneity found among these colleges, and if generalizations are possible.

No significant differences were found on UI, $A K$, and CI. Examination of the remaining eight scales reveals that strong tendencies are readily observable. On three scales, DG, MLN, and IE, Schaffe's test at the .05 level failed to find significant differences. On DG the scores range from 4.96 to 7.94 , all in the middle ranges, and all well within one standard deviation of the means for liberal arts and four-year state colleges. On MLN and IE the 
ranges were even less $(6.40$ to 8.26 and 8.92 to 10.56$)$, and again, with all scores within one standard deviation of the means for both liberal arts and four-year state colleges.

Although the Schaffé test found significant differences on IAE, F, HD, and IS, the scores were clustered on the low end of the scale. On IAE, F, and HD no college scored above the mean for liberal arts colleges or fouryear state colleges, and only two colleges did so on IS. The greatest range of scores is found on SP, where practices appear to vary considerably, thus not allowing a generalization.

Figure 1 shows that the only colleges to distinguish themselves from the others are colleges 1 and 3 --and this only to a limited degree. College l's low scores on IAE, $F$, and $H D$ are distinguishing only because in all three cases they are the lowest scores on scales on which the other colleges have strong tendencies to score low. College $3^{\prime} s$ highest score on HD is significantly different from the scores of two other colleges, but it does not appear to be a drastic deviation from the tendency to score low on this scale when compared to the HD mean of the liberal arts and four-year state colleges. College 3's highest score on SP is the highest in a wide range of scores, but significantly different from only two other colleges of the sample. Only College 3's highest score 
on Is appears to separate it from the sample as a whole. While previous studies have employed different classification systems and environmental assessment tools, the findings of this study are generally supported by previous research on college environments. Astin (1965) found that Protestant liberal arts colleges enrolled students that scored low on the intellectual dimension of the environment. Stern (1970) concluded that the denominational liberal arts colleges were lower on intellectual climate, with less pressure for academic achievement than the independent liberal arts colleges. Pace (1972) found that most protestant colleges scored low on a scholarship aimension, while Hobbs and Meeth (1980) concluded that two-thirds of the Christian colleges stressed behavioral concerns over academic matters. In this study the sample colleges' low scores on IAE and AK appear consistant with these earlier findings. The low scores on IAE and AK are not consistant with stern's findings of an inverse relationship between size and intellectual climate discussed in Chapter II.

The low scores on $\mathrm{HD}$ and $\mathrm{F}$ reflect the findings of Astin (1968), who found the environments of the Protestant colleges somewhat restrictive. stern concluded that the environments at the denominational colleges demanded much social conformity, and Pace found that the Protestant colleges scored high on propriety, that is, a concern for 
rules and social structure. Likewise, the low scores on Is reflect Pace's findings of Protestant colleges being below average on social and political awareness, and Hobbs and Meeth's finding of Christian colleges' emphasis of personal piety over social responsibility. Astin (1968), Stern, and Pace found the Protestant colleges to be high on cohesiveness, group life, and community, which tend to support the sample colleges' high scores on IE.

In sumary, even though significant differences were found, the sample colleges demonstrated homogeneity on the scales of the IFI, except for SP. None of the colleges deviated substantially from the other colleges on more than one or two scales. These conclusions allow for a generic description of the dimensions of the environment at these colleges as measured by the IFI.

\section{Environmental Descriptions}

The publishers of the IFI (Peterson, et al., pp. 1-2) provide interpretations for high and low scores on the 11 scales that, if valid, allow for a generic description of the environments of these six colleges. These colleges exhibited low scores on the environmental scales IAE, HD, and $A K$; and moderately low scores on $F$ and IS. High scores were found on UL and IE, with the remaining five scale scores falling in the midale ranges. Based on the collective perception technique, these 
small liberal arts Christian colleges may be described as institutions that are relatively homogenous in terms of faculty and student ethnicity, social backgrounds, political and religious beliefs, and personal tastes (HD). There are heavy institutional emphases on the teaching of undergraduates, with this being a major priority (UL). There are genuine feelings of community on these campuses, with shared beliefs in the goals and objectives of the institutions, with positive faculty-administrator relationships (IE). They are moderately innovative in their educational practices, and have possibly made curriculum changes in the recent past (CI). They provide some educational and cultural opportunities to their surrounding communities, but this is not a major thrust of the institutions (MLN). The improvement of social conditions and prompting social changes are not direct concerns of these colleges, and few programs or people on the campuses are directly involved with such efforts (IS). They are relatively lacking in extracurricular opportunities of an intellectual and aesthetic nature, such as student literary productions, art exhibits, outside intellectual and artistic guests, etc. (IAE), and there is little support or commitment given to research and scholarship (AK). The faculty and administrators are not free to discuss topics and organize groups of their own choosing or to engage controversial speakers. Students 
and faculty/administors are under numerous institutional restraints concerning their academic and personal lives (F). Administrative structures are such that students and faculty are given moderate amounts of decision-making and input (DG), while long-range planning and institutional research practices vary considerably from college to college (SP).

\section{Sample Colleges-Normative Data Comparisons}

The sample colleges differed significantly from the liberal arts colleges on eight of the 11 IFI scales (see Figure 2). They are perceived to provide far fewer intellectual and aesthetic extracurricular activities on caripus than the the larger liberal arts colleges (IAE), and while the liberal arts colleges do not appear to put high priority on research and scholarship (AK) or programs and activities aimed at the improvement of social conditions (IS), the sample colleges see these areas as even less important. The sample colleges are also perceived to have less diversity on campus in terms of the types of people that work at and attend the colleges (HD), and behavioral and social expectations are more clearly defined and enforced (F). They are slightly more traditional in their educational practices (CI), and have slightly less community involvement than the liberal arts colleges (MLN). Finally, higher feelings 
of community and belief in the objectives of the institution are found on these campuses (IE). Astin and Lee (1972), using the Inventory of College Activities, found that the "invisible colleges" (under which the sample colleges qualify) appeared to be more like public colleges than the private elite colleges. The findings of this study, using the IFI, show that the differences between the sample colleges and four-year state colleges are as great, if not greater, than the differences between the sample colleges and the liberal arts colleges. It must be pointed out however, that the normative data for liberal arts colleges, while containing "elite" colleges, also contains many non-elite and even invisible colleges.

A note of caution must be interjected as to interpreting statistical significant dif̈̈erences as repres'anting real or noticeable differences in a college environment. For example, liberal arts colleges and the sample colleges scored 9.04 and 9.96 respectively on Institutional Esprit. While statistically significant at the .05 level, one might question if the difference in institutional esprit between the two types of colleges would be discernable in a practical sense. The same question might be asked in comparing sample colleges and liberal arts colleges on IS, MLN, and CI, and in comparing the sample colleges and four-year state colleges 
on DG and perhaps SP.

Finally, it should be pointed out that even though

on numerous scales differences do not appear great, these six colleges are being compared to the traditional

classifications of colleges that they are believed to be most like. Had other classifications been chosen for comparison, such as community colleges or comprehensive multi-purpose universities, the distinctive qualities of these institutions may have been more readily apparent. 
CHAPTER V

CONCLUSIONS AND RECOMMENDATIONS

Summary of the study

The Institutional Functioning Inventory, employing the collective perception technique was administered to faculty and administrators at six small liberal arts Christian colleges in an effort to determine if these small institutions of higher education differ in environmental characteristics from the traditional classifications of liberal arts and four-year state colleges.

A multivariate analysis of variance with the sample colleges as the independent variable and the 11 scales of the IFI as the dependent variable resulted in a rejection of the statistical hypothesis. Univariate analyses of variance were performed on the 11 IFI scales, resulting in the rejection of eight statistical hypotheses. Schaffe's test at the .05 level failed to find significant differences on three of the eight scales where the statistical hypothesis had been rejected. Significant differences were found among the colleges on the scales Intellectual-Aesthetic Extracurriculum, Freedom, Human 
Diversity, Concern for the Improvement of Society, and Self-Study and Planning. In spite of these differences, the colleges did exhibit a degree of homogeneity on all scales except self-Study and Planning.

A second multivariate analysis of variance was performed with faculty and administrator status as the independent variable and the 11 IFI scales as the dependent variable. This resulted in the failure to reject the statistical hypothesis. This finding was consistent with other research showing that faculty and administrator perceptions are comparable when using the IFI.

Total sample means on the 11 scales of the IFI allowed for a generic description of 11 dimensions of the environments at these colleges. They were described as environments low on intellectual-aesthetic extracurriculum activities, human diversity, personal and academic freedom, concern for improving society, and concern for advancing knowledge, while being high on institutional esprit and placing high emphasis on undergradiate teaching and learning. The environments were characterized as having moderate amounts of democratic governance, self-study and planning, innovative educational practices, and programs designed to meet the needs of their immediate communities. When compared to liberal arts colleges, the statistic $\underline{z}$ led to the rejection of the statistical 
hypothesis on eight of the 11 scales. The sample colleges scored considerably lower on Intellectual-Aesthetic Extracurriculum, Freedom, Human Diversity, and Concern for the Advancement of knowledge. The lower scores on Concern for the Improvement of Society, Meeting Local Needs, and Concern for Innovation were statistically significant, but the differences between the means of the sample colleges and the means of the liberal arts colleges were much less pronounced. Only on Institutional Esprit did the sample colleges score significantly higher. Eight statistical hypotheses were also rejected when comparisons were made between the sample colleges and the four-year state colleges. The sample colleges were most distinguished by considerably lower scores on Intellectual-Aesthetic Extracurriculum, Freedom, and Human Diversity, and by higher scores on Concern for Undergraduate Learning and Institutional Esprit.

\section{Conclusions}

It is concluded from this study that these small liberal arts Christian colleges are a relatively homogeneous group, even though there are some variations. In addition, they differ significantly and practically from liberal arts colleges and four-year state colleges with respect to numerous environmental dimensions. 
The first major research question dealt with the common and differing perceptions of the environments among the institutions and between faculty and administrators. In addition, it was asked what type of environments were perceived. When the data were analyzed by institutions:

1. No differences were found among the colleges on the scales of Concern for Advancement of Knowledge, Concern for Undergraduate Learning, and Concern for the Improvement of society.

2. Significant differences were found among the colleges on the remaining eight dimensions.

3. If differences did exist between the perceptions of the faculty and administrators, they were not detected by this study.

In spite of the significant differences found on eight of the 11 IFI scales, these colleges are a relatively homogeneous group. Scoring patterns emerged on the scales that suggested common perceptions of the environments were present. No two environments are exactly alike, and this study detected the statistically significant differences among the colleges. Yet, it is reasonable to conclude that these colleges are similiar in the environmental dimensions measured by the IFI. The total sample environmental description is a generalization that is close to a description of any individual sample college. 
The second research question was concerned with how the perceptions of the environments at these sample colleges compared with the perceptions of the environments at liberal arts colleges and four-year state colleges. The results of the study have shown that:

1. Statistically significant differences exist between the sample colleges and both the liberal arts and four-year state colleges on eight of the 11 IFI scales. However; 2. It is also reasonable to conclude that there are significant and practical differences between the environments of the sample colleges and the environments at both the liberal arts and four-year state colleges. 3. The environments of the sample colleges are more similar to the environments of the liberal arts colleges than to those of the four-year state colleges.

The stated purpose of this study was to determine if the small liberal arts Christian colleges provide unique college environments apart from the traditional classifications of colleges and universities. The conclusion is that they do, indeed, provide a unique college environment. This study has shown that their environments are most distinctive in that they provide very few extracurricular activities of an intellectualaesthetic nature, place many restraints on the academic and personal lives of faculty and students, place a low 
priority on research and scholarship, and are relatively homogenous in the beliefs and backgrounds of the students and faculty present on campus.

The propensity of some may be to immediately question the value of institutions with the characteristics of these colleges as portrayed in this study, or any college that scores low on certain of these environmental scales. The publishers of the IFI warn against such conclusions.

Any notions regarding the value to attach to the fact of a relatively high or low score on a given scale can come only from consideration of the institution's traditions, priorities, and purposes. High scores on the IFI scales are not to be regarded as "good," nor low ones as "poor," lintil or unless judgements beyond the scope of these norms are made (Peterson, et al., 1970, p. 39).

Nonetheless, as these institutions come under financial and enrollment pressures, the burden of proof as to the value of such college environments will fall on these institutions.

\section{Recommendations}

The small liberal arts Christian college has been placed in a vulnerable category of colleges for the coming years. It has been suggested (Carnegie Foundation, 1975; Pace, 1972) that those institutions that most clearly establish their distinctiveness and role in 
higher education will stand the best chances for survival. To accomplish this task, further research is needed to complete the picture of the nature of these institutions and the constituencies they serve.

The nature of the research in this study was extensively quantitative and descriptive, and did not attempt to answer why these small liberal arts Christian colleges create the environments that they do. Qualitative research, such as indepth interviews with faculty, administrators, and students will aid in the understanding of why these environments are perceived as lacking diversity, freedom, and intellectual activities. Such research should focus on the nature and role of the institutions' Christian beliefs, and how they are seen to affect the environment. Such qualitative research would also serve to validate or invalidate the generic description generated by this study.

Additional environmental studies employing other methods and instruments will reveal characteristics not identified by the IFI. Studies of faculty and student characteristics and personalities at these colleges will aid not only in understanding the environment, but will also aid in the identification of a constituency that is interested in such colleges. Research focusing on the institutional goals and the corresponding institutional 
environmental dimensions will greatly aid in determining the degree of success these colleges are experiencing in fulfilling their stated purposes.

The colleges in the sample were located within one state. Replication of the study in various geographical sections of the country would allow for greater generalizations, or could serve to identify the role of geographic location as a variable for determing a college's environment.

Finally, the desirability of any environment should be determined by the effect it has on students. Research focusing on the satisfaction and/or dissatisfaction with the various components of the educational experience at these colleges will provide information that would allow the colleges to enhance certain environmental dimensions that are controllable. In addition, efforts must also center on the identification and recruitment of the types of students that experience optimal growth in these environments. Such efforts will strengthen the attractiveness of these colleges and enhance their viability. 


\section{BIBLIOGRAPHY}

Anstett, R. R. A study of transfer student perceptions of a campus environment. NASPA Journal, 1973, 10 (3), $198-205$.

Astin, A. W. Who goes where to college? Chicago, Illinois: Science Research Associates, 1965.

Astin, A. W. The college environment. Washington, D.C.: American Council on Education, 1968.

Astin, A. W., \& Holland, J. L. The environmental assessment technique: a way to measure college environments. Journal of Educational Psychology, 1961, $\underline{52}, 308-316$.

Astin, A. W., \& Lee, B. T. The invisible colleges: A profile of small, private colleges with limited resources. New York: McGraw-Hill, 1972.

Benn, G. C. A comparison of the ideal and real college environment as perceived by entering freshmen in an Oklahoma State University (Doctoral dissertation, Oklahoma State University, 1975).

Dissertation Abstracts International, 1975, 36, $7228 \mathrm{~A}$.

Brooks, N. J. The future of private colleges. Research in Education: 1980. (ERIC Document Reproduction Service No. ED 184 476)

Buros, O. K. (Ed.). Seventh mental measurements yearbook (Vol. 1). Lincoln, Nebraska: University of Nebraska Press, 1972.

Carnegie Commission on Higher Education. Quality and equality: New levels of federal responsibility for higher education. New York: McGraw-Hill, 1970.

Carnegie Commission on Higher Education. New students and new places: Policies for the future growth and development of American higher education. New York: McGraw-Hill, 1971. 
Carnegie Commission on Higher Education. Reform on campus: Changing students, changing academic programs. New York: McGraw-Hill, 1972.

Carnegie Commission on Higher Education. Priorities for action: Final report of the Carnegie Commission on Hiqher Education. New York: McGraw-Hill, 1973(a).

Carnegie Commission on Higher Education. The purposes and performance of higher education in the United States: Approaching the year 2000. New York: McGraw-Hill, $1973(b)$.

Carnegie Council on Policy Studies in Higher Education. A classification of institutions of higher education (revised edition). Berkeley: Carnegie Council on Policy Studies in Higher Education, 1976.

Carnegie Council on Policy studies in Higher Education. The states and private hiqher education: Problems and policies in a new era. San Francisco: JosseyBass, 1977.

Carnegie Council on Policy Studies in Higher Education. Three thousand futures: The next twenty years for higher education. San Francisco: Jossey-Bass, 1980.

Carnegie Foundation for the Advancement of Teaching. More than survival: Prospects for higher education in a period of uncertainty. San Francisco: Jossey-Bass, 1975.

Centra, J.A. College enrollments in the 1980's: projections and possibilities. Journal of Hiqher Education, $1980, \underline{51}(1), 18-39$.

Chickering, A. W. Undergraduate academic experience. Journal of Educational Psychology, 1972, $\underline{63}(2)$, $134-143$.

Chickering, A. W., McDowell, J., \& Campagna, D. Irstitutional differences and student development. Journal of Educational Psychology, 1969, 60 (4), 315-326.

Clarke, R. B., Coladarci, A. P., \& Caffrey, J. Statistical reasoning and procedures. Columbus, Ohio: Charles E. Nerrill, 1965 . 
Crossland, F. E. Learning to cope with a downward slope. Change, July-August 1980, pp. 18-25.

de Armas, C. P., \& McDavis, R. J. White, black, and hispanic students perceptions of a community college environment. Journal of College student Personnel, $1981, \underline{22}(4), 337-341$.

Feldman, K. A., \& Newcomb, T. M. The impact of college on students (2 vols.). San Francisco: Jossey-Bass, 1969 .

Frances, C. Apocalyptic vs. strategic planning. Change, July-August 1980, pp. 39-44.

Glenny, L. A. Demographic and related issues for higher education in the 1980 's. Journal of Higher Education, $1980,51(4), 363-380$.

Goodwin, G. C. Differential perceptions of a university environment: freshmen and seniors. College student Journal, $1980, \underline{14}(4), 408-411$.

Grant, C. M. An institutional self-study: Internal functions surveyed through its faculty and administration (Doctoral dissertation, University of Utah, i975). Dissertation Abstracts International, $1975, \underline{36}, 3279 \mathrm{~A}$.

Guth, J. E. Junior college transfer students' perceptions of the academic environment of their former junior college and Auburn University (Doctoral dissertation, Auburn University, 1974). Dissertation Abstracts Irternational, 1974, 35, 3424A.

Hamilton, J. T. A comparison of domestic and international studerts' perceptions of the university environment. Journal of College Student Personnel, 1979, 20 (5), $443-445$.

Hartnett, R. T., \& Centra, J. A. Faculty views of the academic environment: Situational vs. institutional perspectives. Sociology of Eaucation, 1974, 47, $159-169$.

Hobbs, W. C.. \& Meeth, L. R. Diversity among Christian colleges. Arlington, Virginia: studies in Higher Education, 1980 . 
Hodgkinson, H. L. Institutions in transition: A study of change in higher education. New York: McGrawHill, 1970 .

Jonsen, R. W. Small liberal arts colleges: Diversity at the crossroads? Washington, D. C.: American

Association for Higher Education, 1978. (ERIC Document Reproduction Service No. ED 154 680)

Keeton, M. T. Models and mavericks: A profile of private liberal arts colleges. New York: McGraw-Hill, 1971.

Kroeker, L. D. The relationship between faculty, student, and administrator: Perceptions of goals and practices of a state four-year institution (Doctoral dissertation, University of Oklahoma, 1973). Dissertation Abstracts International, 1973, 35, $218 \mathrm{~A}$.

Kuh, G. M., \& sturgis, J. T. Looking at the university through different sets of lens: Adult learners and traditional age students' perceptions of the university environments. Journal of College student Personnel, $1980, \underline{21}(6), 483-490$.

Lawson, C. R. Comparisons of the university environment as perceived by freshmen, upperclassmen, faculty, and administrators at the University of Southern Mississippi (Doctoral dissertation, University of Southern Mississippi, 1974). Dissertation Abstracts International, $1974, \underline{35}, 2723 \mathrm{~A}$.

Leslie, L. Patterns of enrollment in higher education 1965 to 1977 . Liberal arts colleges. Tucson, Arizona: Center for the Study of Higher Education, College of Education, University of Arizona, 1981. (ERIC Document Reproduction Service No. ED 208 747)

Madrazo-Peterson, R., \& Rodriquez, M. Minority students' perceptions of a university environment. Journal of College Student Personnel, $1978, \underline{19}(3), \frac{\text { ournal }}{259-263}$.

McDonald, T. R. Black and white graduate student perceptions of university environment (Doctoral dissertation, University of Miami, 1972). Dissertation Abstracts International, 1972, 33, 5323A. 
Menne, J. W. Techniques for evaluating the college environment. Journal of Educational Research, 1967. $\underline{4}(4), 219-225$.

Murray, H. A. Explorations in personality. New York: Oxford University Press, 1938.

Murray, W. R. Ethnic and sex differences as related to student perceptions of a university environment (Doctoral dissertation, New Mexico state University, 1972). Dissertation Abstracts International, 1972, 33, $2663 \mathrm{~A}$.

National Center for Educational Statistics. Digest of educational statistics. Washington, D. C.: U. S. Government Printing Office, 1970, 1975, 1981.

National Center for Educational Statistics. The condition of education: A statistical report. Washington, D. C.: U. S. Government Printing Office, 1982.

Nell, B. C. A study of the purposes, practices, and goals as perceived by selected groups in a small experimental liberal arts college. Unpublished doctoral dissertation, Indiana University, 1973.

Nelson, G. T. A private, liberal arts college as perceived by its several populations: A descriptive study (Doctoral dissertation, University of of Arkansas, 1972). Dissertation Abstracts International, 1972, 33, $2131 \mathrm{~A}$.

Pace, C. R. College and university environment scales: Second edition technical manual. Princeton, New Jersey: Education Testing Service, 1969 (a).

Pace, C. R. College environments. In R. L. Ebel (Ed.), Encyclopedia of educational research: New York: Macmillian, 1969 (b) .

Pace, C. R. Education and evangelism, a profile of Protestant colleges. New York: McGraw-Hill, 1972.

Pace, C. R. The demise of diversity? A comparative profile of eight types of institutions. New York: McGraw-Hill, 1974 .

Pace, C. R.. \& Stern, G. G. An approach to the measurement of psychological characteristics of college environments. Journal of Educational Psychology, $1958, \underline{49}, 269-277$. 
Patillo, M. Jr., \& Mackenzie, D. M. Church-sponsored higher education in the United States: Report of the Danforth Commission. Washington D. C.: American Council on Education, 1966.

Peterson, R. E., Centra, J. A., Hartnett, R. T., \& Linn, R. Institutional functioning inventory: Preliminary technical manual. Princeton, New Jersey: Educational Testing Service, 1970.

Rick, H. E., \& Jolicoeur, P. M. A comparison of college structure and college environment variables as predictors of student orientations. Journal of College Student Personnel, 1979, 20, 215-223.

Roussell, N. Sub-populations' perceptions of Dillard University (Doctoral dissertation, Wayne state University, 1974). Dissertation Abstracts International, $1974, \underline{35}, 4207 \mathrm{~A}$.

Spangler, C. M. Real and ideal university environments as perceived by students, faculty, and administrators (Doctoral dissertation, New Mexico State University, 1972). Dissertation Abstracts International, 1972, 33. 595A.

Stern, G. G. People in context: Measuring person-evironment congruence in education and industry. New York: John Wiley and Sons, 1970.

Wildman, L. The relationships between student perceptions of a college and student transfer. College student Journal, $1972, \underline{6}(4), 57-63$.

Windham, P. A. Assessment of the North Texas State University campus environment through perceptions of institutional characteristics held by selected sub-groups of the student body (Doctoral dissertation, North Texas State University, 1973). Dissertation Abstracts International, 1973, 34 $1663 \mathrm{~A}$.

Wright, J. I. A factor analytic study of three measures of college environments. Unpublished doctoral dissertation, University of Maine, 1973. 